\title{
Building the Architectural Narrative of the Topkapı Kara Ahmed Pasha Mosque Complex in Early Republican Turkey
}

\author{
Serra Akboy-ílk*
}

\begin{abstract}
The Kara Ahmed Pasha Mosque complex in Topkap1, Istanbul, a sixteenth-century monument, is one of the beacons in the architectural historiography created during the early republican period in Turkey. Noted in Mimar Sinan's autobiographies, the mosque became an academic subject of formalist monographs and research. The early republicans' formalist construct of the historic complex resonated with the theory of modern architecture. Function was not seen as an autonomous facility that had to be connected with other contextual facets but as an internal force through which architectural form emerged. Hence, Sinan's devised form for the mosque was merely conceived as the outcome of the chief architect's rational consideration of function and structure. In return, the formal appreciation of the historic compound devoted itself single-mindedly to the aesthetic properties of architecture and muted contextual analysis as a research inquiry. This essay provides a closer reading of the early republican historiography on the Kara Ahmed Pasha Mosque complex to unveil the formal references that have perpetuated the long-standing understanding of the historic complex.
\end{abstract}

Keywords: Kara Ahmed Pasha Mosque complex, Mimar Sinan, formalist analysis, early republican Turkey, historiography

Topkapı'da bulunan Kara Ahmed Paşa Külliyesi'nin Erken Cumhuriyet Dönemi'nde Mimari Anlatımının Şekillenmesi

Özet

On altıncı yüzyıl mimari eserlerinden, Topkapı'da bulunan Kara Ahmed Paşa Külliyesi, erken cumhuriyet döneminde üretilen tarih yazımı çalışmalarının odak noktalarından biri olmuştur. Mimar Sinan'ın otobiyografilerinde bahsi geçen külliye, dönemin biçimsel çözümlenmiş monografilerinde ve çalışmalarında yer almıştır. Erken cumhuriyet dönemi aydınları, Kara Ahmed Paşa Külliyesi'ni modern mimarlık teorisi ekseninde biçimsel değerlendirmiştir. Mimari işlev, bağlamsal özelliklerden bağımsız tutulmuş, form içsel bir hüküm olarak tanımlanmıştır. Bu bağlamda, Mimar Sinan'ın Kara Ahmed Paşa Cami için ürettiği mimari form, mimarbaşının kendi rasyonel değerlendirmesi olarak görülmüştür. Böylece, Kara Ahmed Paşa Külliyesi'nin biçimsel analizi estetik hükümlere odaklanmış ve bağlamsal çözümlemeler göz ardı edilmiştir. Bu makale, erken dönem cumhuriyet tarihyazımı kapsamında Kara Ahmed Paşa Külliyesi’ni incelemekte ve artık kemikleşmiş olan biçimsel anlayışını ele almaktadır.

Anahtar Kelimeler: Kara Ahmed Paşa Külliyesi, Mimar Sinan, biçimsel analiz, erken cumhuriyet dönemi, tarihyazımı

Commissioned by the grand vizier Kara Ahmed Pasha (fl. 1553-1555), who served in the court of Süleyman (r. 1520-1566), the mosque complex (fig. 1-2) was constructed on an intermittent schedule, overlapping 1555 and 1565-1571/72. The monument is a work of Mimar Sinan (1489-1588), the prolific royal master builder and engineer in the service to the Ottoman court. In the autobiographies of Sinan, Tezkiretü'l ebniye and Tuhfetül-mi'mãrin, the Kara Ahmed Pasha Mosque is accounted among seventy-seven Friday mosques built during Sinan's tenure as the chief architect of the Corps of Court Architects (fl. 1538-1588). Not surprisingly, its association with Sinan's unique legacy brought the Kara Ahmed Pasha Mosque

"Collin College, serraakboy@yahoo.com 
(also known as the Gazi Ahmed Pasha Mosque) under early republican scholars' intellectual radar. The Directorate-General for Pious Foundations conducted a restoration campaign of the mosque complex, followed by the publication of the 1942 monograph, Kara Ahmed Paşa Vakfiyesi / Topkapi'da Ahmed Paşa Heyeti, written by Şerefüddin Yaltkaya and Ali Saim Ülgen (fig. 3). ${ }^{1}$ Furthermore, the mosque complex became a recurring subject in the formal surveys of Sinan's architecture.

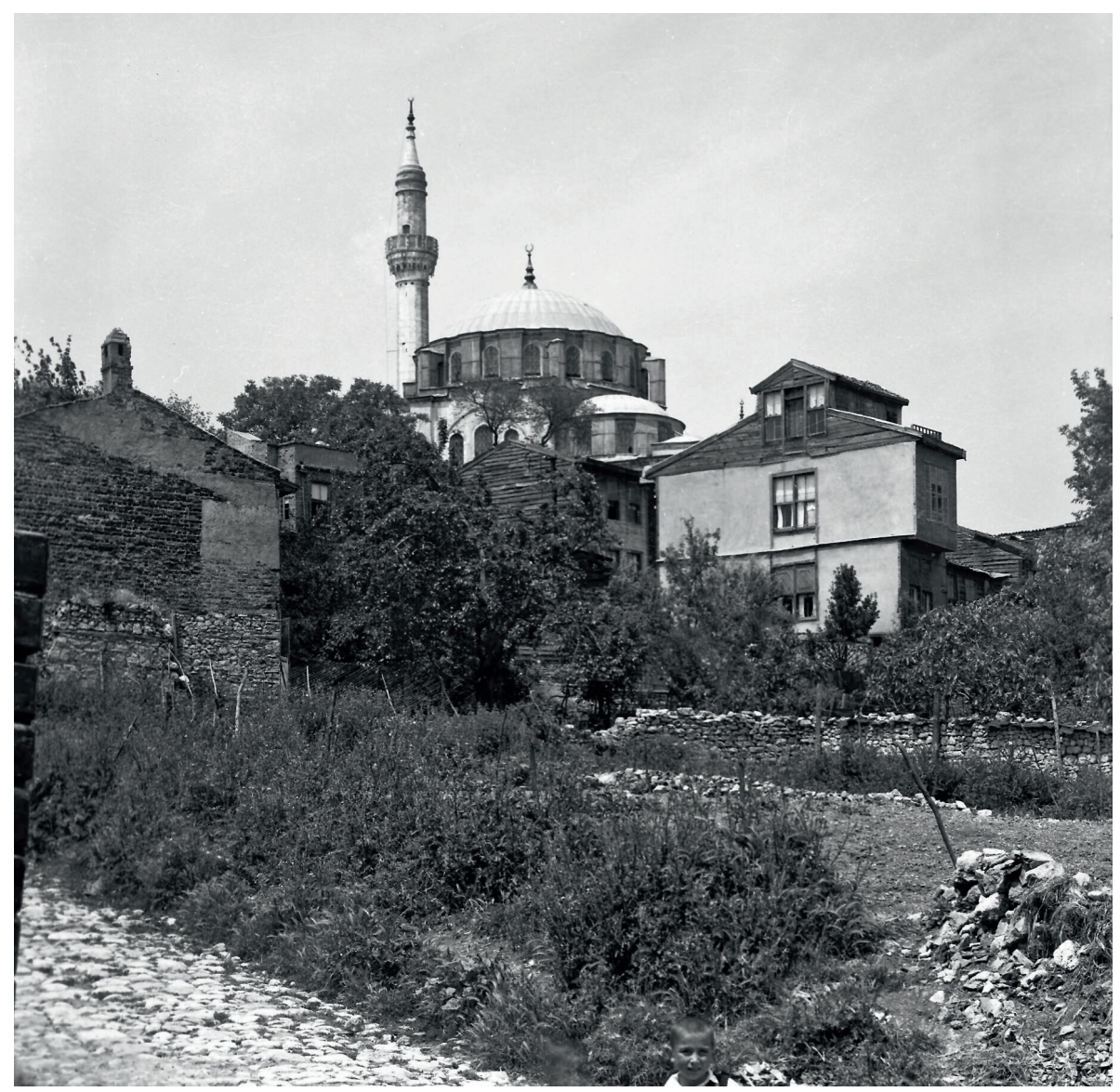

First emerging in German philosophical aesthetics in the nineteenth century, formalism was concerned with the perception of forms ${ }^{2}$ in the absence of any meaning. The convention of interpretation defined an ideal moment in a purely conceptual space where works of art were imagined to be spontaneous, internalized (outside circumstantial reality), and assimilable as pure idea. Subsequently, formalism allowed the aesthetic attitude to attend to pure formal values of art. Construed as a methodological approach, the formalist inquiry was extensively applied to the criticism and practice of literature, music, and performing arts along with architecture. The approach derived its explanations between parts of a work, be they musical notes, words, colors, marks, or volumes. A conscious avoidance of historical facts accompanied the formal system; how a cultural object in time is possessed, rejected, or achieved was not addressed in this particular school of thought.

1 Şerefüddin Yaltkaya and Ali Saim Ülgen, Kara Ahmed Paşa Vakfiyesi / Topkapı'da Ahmed Paşa Heyeti (Ankara: Vakıflar Umum Müdürlüğü Neșriyatı, 1942).

2 Form is the physical appearance of a building. Shape (outline), size (dimensions), color (visual weight), texture (how light is absorbed or reflected from the building surface), position (location in the environment), and orientation (in relation to ground) are attributes of form.
Figure 1: Kara Ahmed Pasha Mosque, street view. SALT Research, Ali Saim Ülgen Archive, TASUH7937. 
Figure 2: Kara Ahmed Pasha Mosque, courtyard view. SALT Research, Ali Saim Ülgen Archive TASUH4648.

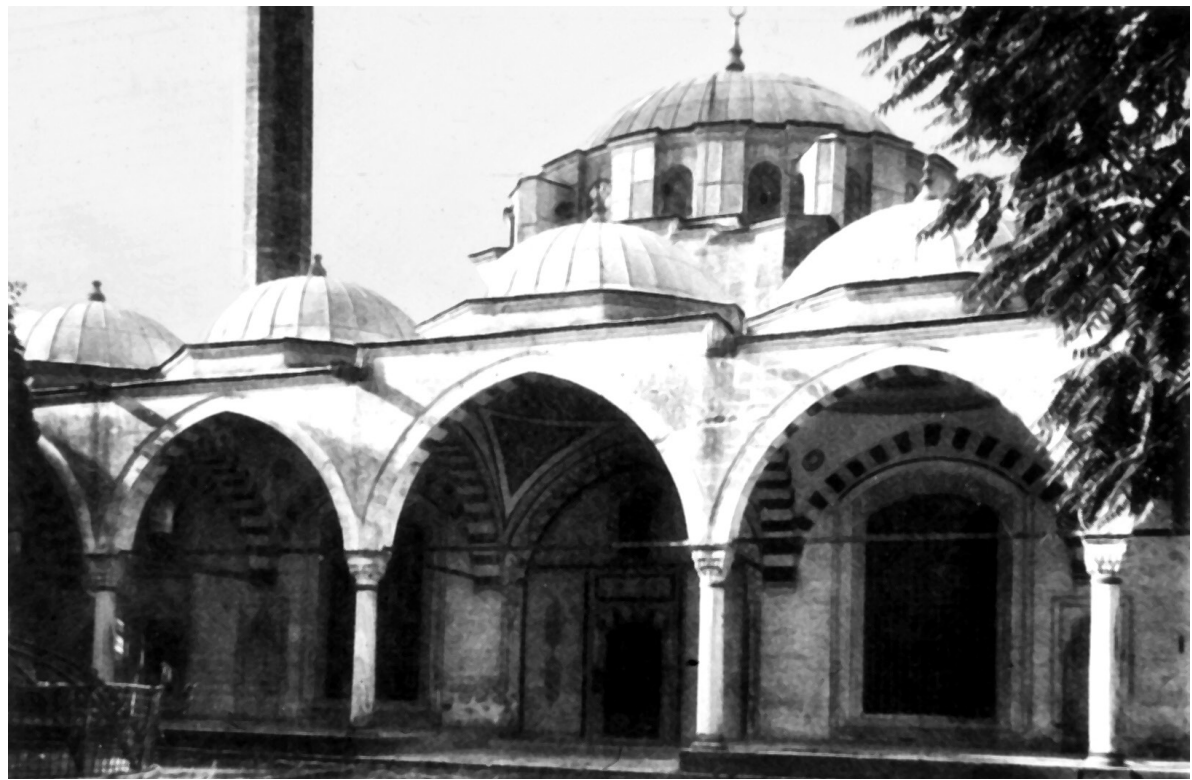

Figure 3: Site plan of the Kara Ahmed Pasha Mosque complex (Ülgen, Topkapi'da Ahmed Paşa Heyeti, 172).

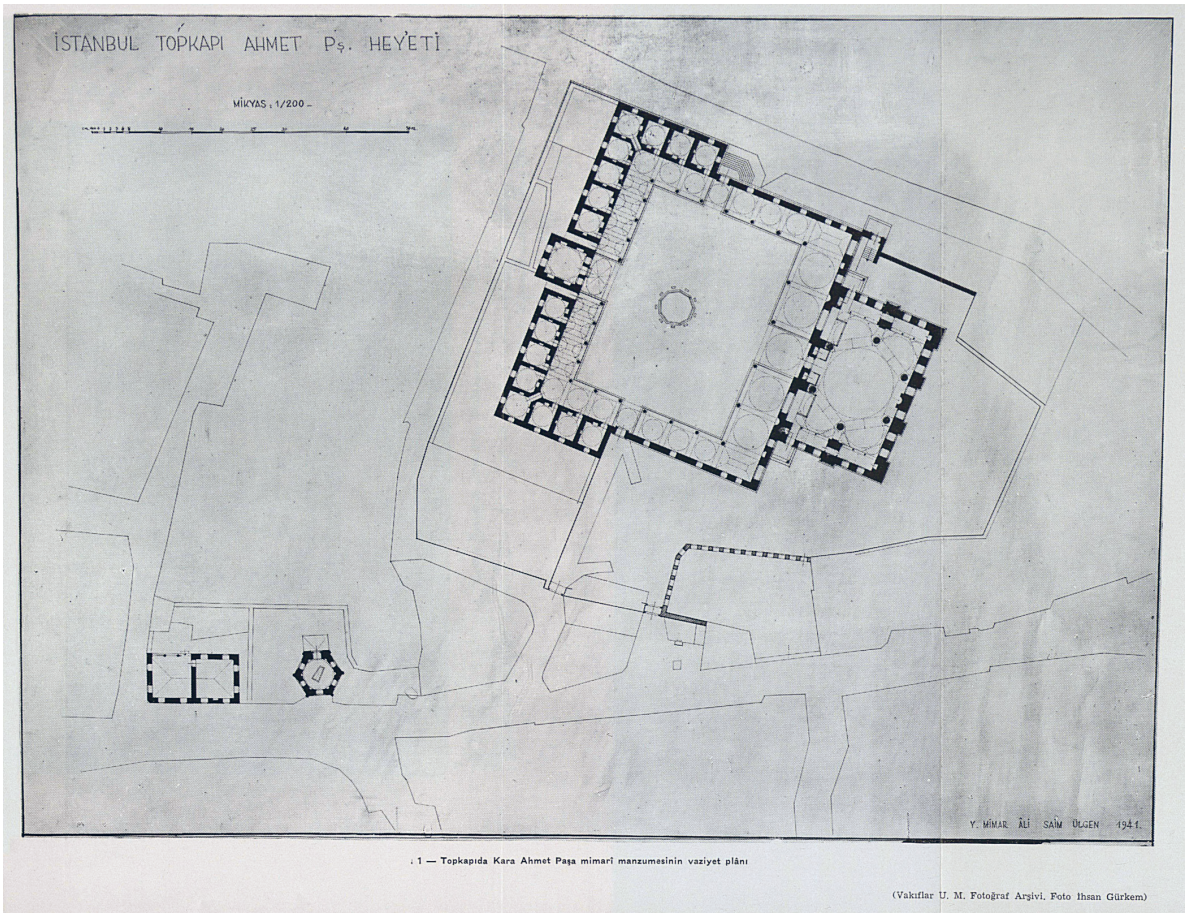

Remarkably, the formalist mind enabled powerful mediums to convey partisan messages, in particular during modern constructions of nation building. One example includes the early years of the Republic of Turkey, ${ }^{3}$ when the founding leaders framed a nationalist state-agenda, which promoted the exclusiveness of national unity among Turks. The state propaganda, Türk Tarih Tezi (Turkish History Thesis), formulated the roots of the nation in the Turkic tribes of Central Asia. Among the migration routes from the east to the west, Turks brought their

3 I define early republican Turkey from 1923, the formation of the Republic of Turkey, to 1945, the beginning of multi-party politics. During this period, Turkey was ruled by the Republican People's Party (Cumhuriyet Halk Partisi), which was presided by legendary leader Mustafa Kemal Atatürk until his death in 1938. This decade exhibits a very strong culture dedicated to documentation, scholarship, and research. 
84 civilization and transformed other cultures. The Turkish identity, consequently, resonated with the ancient Hittite people in Anatolia, the Greek culture of the classical antiquity, and even with Roman society through the Etruscans. Symbolically, the Thesis placed the "Turkish race" at the forefront of world historical development through the ages and portrayed it as being related to the region's ancient civilizations to which European nations also traced their cultural ancestry. ${ }^{4}$

When considered as part of a visual culture, architectural remains gained central importance in the national plot to competitively demonstrate evidential expressions. Supported by state agencies, republican scholars, with supreme patriotic zeal and diligence, traveled across the remotest corners of the country to document and study the historic architecture of the nation. ${ }^{5}$ Resulting publications stipulated a patently ahistorical and strictly formalist realization, where the complicated histories of architecture were relegated to descriptive texts, measured drawings, and photographs. Although these resources, including the records on the Kara Ahmed Pasha Mosque complex, highly resonate with their capacity as reference materials (e.g., for the establishment of names, years of construction, and plan types), they are still extensively used in contemporary architectural research and scholarship due to their unmatched rigor in content. Some of these records, furthermore, constitute the only remaining documents of rapidly vanishing historic resources upon Turkey's history and culture due to neglect, natural disasters, and uncontrolled urban development.

Sibel Bozdoğan and Gülru Necipoğlu rightly probe that the early republican studies, to a large scale, did not commit to the historical and sociocultural conditions that brought forward architecture. ${ }^{6}$ In search of the unifying essence of Turkish architecture, early republican scholars got actively engaged in mapping the national compartments of the visual heritage. Their focus included a normative assessment of architectural historiography, attributed to the common denominator of the Turkish culture. Most surveys on Turkish art and architecture perpetuated this taxonomy by classifying the whole visual heritage in the country as an essentially national building tradition often accompanied by comparative analyses of building typologies and morphologies. ${ }^{7}$ The preoccupation with an essentialized Turkish identity privileged formative origins over processes of historical development and stressed artistic unity over diversity. Without the contextual narrative contained in a building (e.g., the reason for its creation or its operational duties in the historical milieu), the edifice then became a formal presentation of aesthetical qualities.

In a judgment of purity of architectural elements, a fit between Sinan's cognitive hierarchy and resulting artistic form became operative. It was believed that Sinan, albeit subconsciously, in all times and places, was concerned with arrangements of the pure elements of design. No prior knowledge on the design-build process or the reception of Sinan's designs was required to reach this essentialist reading. Such formal analysis catapulted Sinan's works into structural units with the belief that the chief architect developed his designs along a linear path of creative progress and replicated his schemes to all populations and situations. Accordingly, the Kara Ahmed Pasha Mosque was framed as an exploratory design in the development of a hexagonally domed baldachin, which reached an apogee in the Selimiye Mosque, in Edirne (ca. 1568-1574). In this matrix, Kara Ahmed Pasha's mosque was classified with the chief architect's

4 Etienne Copeaux, Tarih Ders Kitaplarında (1931-1993), Türk Tarih Tezinden Türk islâm Sentezine, trans. Ali Berktay (lstanbul: Iletişim Yayınları, 2006), 59-61; Gavin D. Brockett, How Happy to Call Oneself a Turk: Provincial Newspapers and the Negotiation of a Muslim National Identity (Austin: University of Texas Press, 2011), 74; Nilüfer Öndin, Cumhuriyet'in Kültür Politikası ve Sanat 1923-1950 (Istanbul: Insancıl Yayınlar1, 2003).

5 Internalized as a national duty, early republican intellectuals were expected to project their knowledge and experience to an idealistic future of their own society. This revolutionary spirit of the early republic was still prevalent until the 1980 Turkish coup d'état. Between 1960 and 1980, architects focused on utopian projects to shape the society of the future; see Esra Akcan, "Asilik sonrası Mimarlık," in Osmanlı Başkentinden Küreselleşen İstanbul'a: Mimarlı ve Kent, 1910-2010 (Istanbul: Osmanlı Bankası Arşiv ve Araştırma Merkezi, 2011), 134.

6 Sibel Bozdoğan and Gülru Necipoğlu, "Preface: Entangled Discourses," in "History and ldeology: Architectural Heritage of the 'Lands of Rum," ed. Sibel Bozdoğan and Gülru Necipoğlu, special issue, Muqarnas 24 (2007): 1-6. This volume was a resulting publication of the symposium "Historiography and ldeology: Architectural Heritage of the 'Lands of Rum," held in May 2006 under the auspices of the Aga Khan Program for Islamic Architecture at Harvard University. The papers examine some of the major literature, historical personas, and formalist narratives that have tailored the historiography of architecture.

7 For example, Oktay Aslanapa, Turkish Art \& Architecture (New York: Praeger Publishers, 1971). Also, see, Suut Kemal Yetkin, Türk Mimarisi (Ankara: Bilgi Yayınevi, 1970); Behçet Sabri Ünsal, Turkish Islamic Architecture in Seljuk and Ottoman Times, 1071-1923 (London: Alec Tiranti, 1970). 
Figure 4: Floor plans of comparable mosques with hexagonal baldachins,

(a) Sinan Pasha Mosque, (b) Kara Ahmed Pasha Mosque, (c) Sokollu Mehmed Pasha Mosque,

(d) Atik Valide Mosque

(Kuban, "Architecture of the Ottoman Period,"

The Art and Architecture of Turkey, 146).
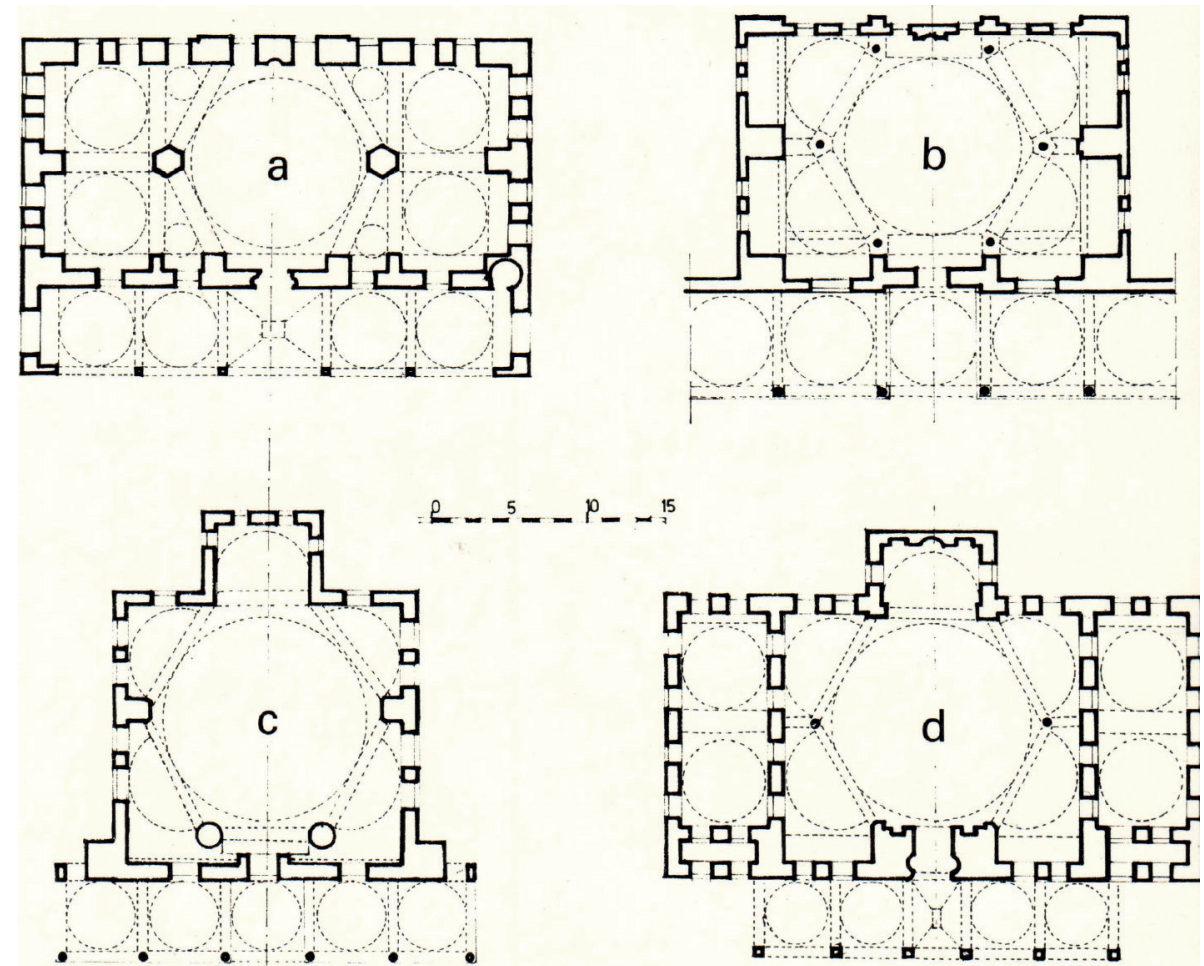

other monuments with comparable polygonal domes, such as the Sinan Pasha Mosque, Atik Valide Mosque, and Sokollu Mehmed Pasha Mosque (fig. 4). ${ }^{8}$

On the other hand, Necipoğlu correctly assesses that the grand vizierial memorial of the pasha exhibits the politics of monumental mosque construction in the sixteenth century. Educated in the imperial palace, Ahmed Pasha "the Black" (Kara) rose through the ranks, becoming the agha of janissaries, governor-general of Rumelia, then the second vizier while serving as the commander-in-chief of Süleyman's second Safavid expedition in 1548-1549. The pasha served as the grand vizier between 1553 and 1555, replacing the deposed grand vizier Rüstem Pasha (fl. 1544-1553 and 1555-1561). By Süleyman's order, in 1555 Kara Ahmed Pasha was executed, followed by Rüstem Pasha's second tenure as the grand vizier (fig. 5). Although Kara Ahmed Pasha began planning his endowment during his service as the grand vizier, the royal complex could not materialize due to his sudden death. ${ }^{9}$ Furthermore, its posthumous construction in Edirnekapı coincided with the efforts of Princess Mihrümah, the prominent daughter of Süleyman and wife of Rüstem Pasha, to build a mosque complex at a distance. Followed by years of bureaucratic and funding negotiations for a building site, in this feud between a beloved daughter and a disgraced grand vizier, Süleyman favored Mihrümah. Kara Ahmed Pasha's royal compound was programmatically scaled down, and the projected building site was moved from Edirnekapı to Topkap1. ${ }^{10}$

Figure 5: Execution of Kara Ahmed Pasha. Lokman, Hünernâme, Topkapı Palace Museum Library, H.1524, V. 177B; SALT Research, AMIMo19.
Located between Yenibahçe and Edirnekap1, the Kara Ahmed Pasha Mosque complex is at a distance from the Topkap1 Gate of the city walls. The mosque and U-shaped madrasa share a garden court. An off-center, ablution fountain ${ }^{11}$ marks the lateral courtyard entrances and the mihrab axis of the mosque. The mausoleum and elementary school are situated across a lane, outside the precinct wall of the mosque and madrasa. The school building faces the 


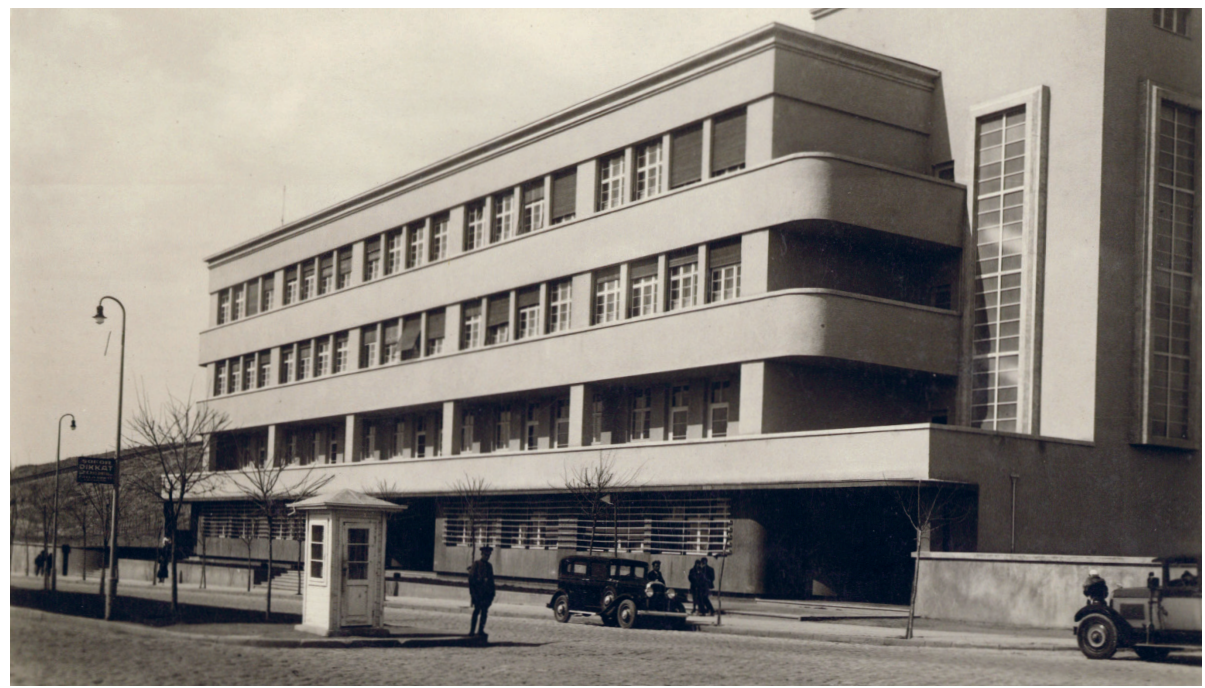

Figure 6: İsmet Pasha Institute for Girls, Ankara, street view, an example of the modern design devised by Ernst A. Egli, built in 1930 . SALT Research, AHANKA134.

cemetery of the mausoleum, which has its own precinct wall. A now lost sebil (public fountain) was located near the mausoleum of the pasha.

My essay resonates with a very straightforward proposition. The underlying problem confronting the early republican formalists included their dedication to articulate the origins of architectural design and to register the autonomy of form as opposed to any message conveyed by it. Both practicing architects and speculating art historians were caught up in the dispute as they strove to locate architectural paragons in the matrix of national architecture. To trace in any details of this controversy, which now seems to have been forgotten, would be an immense and thankless task. Probing formal codes of knowledge, however profitably, could distinguish the methodological biases of architectural texts written in the early republican period. In this context, a closer reading of the early republican historiography on the Kara Ahmed Pasha Mosque complex would unveil the formal references that have perpetuated the long-standing understanding of the historic complex.

\section{Formal Appropriation of the Ottoman Built Environment}

Formalist ideas were deep seated in the conception of modern design emerging at the turn of twentieth century and prevailing until the $198 \mathrm{os}$. Modern design is based on the idea that form should follow function (functionalism), architecture should embrace minimalism, and architectural composition should reject ornamentation. In this sense, modern architecture resonates with the use of innovative construction technologies accompanied by new structural materials like glass, steel, and reinforced concrete (fig. 6). Often associated with two-dimensional realization of design (of plans, sections, and elevations), formalism dictated a reliance on a prescribed order of an abstract geometrical discipline in modern design, such as "composition, symmetry, order, module, proportion, "literacy in plan, construction, and appearance."'12

At a more symbolic level, early republican scholars sought to reconcile the nationalist historiography of architecture with modernist practice. ${ }^{13}$ Primarily conceptualizing Ottoman

12 Reyner Banham, The New Brutalism (Stuttgart: Karl Kramer Verlag, 1966), 68. With this token, Banham states that modern architecture was considered to abandon the idea of the architect's prime function to make spaces.

13 "International style," also known as "cubic style" in Turkey, became prevalent in the early republican architectural practice, since its modern design represented a forward-looking attitude. A major irony in the history of modernism was, however, the reconciliation of international style during the domination of strong nationalist sentiments in the practice of architecture. Modernist Turkish architects vehemently opposed the term "international style" and insisted on the name, "new architecture," which was neither "international" nor "a style." "New architecture" was supposed to be the most rational response to site, program, climate, and context, and thus it was "national." Yet, the dispute between the anti-stylistic taste of modernism and the domination of elements of modern design (cubic form, flat roofs, horizontal window bands, and the like) created an ongoing tension; see Sibel Bozdoğan and Esra Akcan, Turkey: Modern Architectures in History (London: Reaktion Books, 2012), 18-19. In retrospect, the constant debate between national and international 
architecture as a rational, tectonic, and functional building tradition, distinct from other examples of oriental and Islamic architecture and closer in spirit to the modern design, the republican intelligentsia sought to establish transhistorical affinities between building traditions of Turks and the modernist avant-garde in Europe. ${ }^{14}$ If they could ascertain that the national architecture of Turks was already modern and rational, meaning that the historical patrimony embodied the same qualities advocated by modernism (of simplicity, functionality, austerity and lack of ornamentation), the republican quest of placing the country on the civilized side of the East-West cultural divide would be automatically achieved. ${ }^{15}$

Gülsüm Baydar Nalbantoğlu argues that the interest to frame a rationalist vision of national architecture was manifested in the analysis of vernacular building traditions in the early years of the republic. To assign the Turkish house compatible with tenets of European modernism, architect-scholars established a narrative of an ahistorical rationalist vision of regional traditions. Sedad Hakk1 Eldem (1908-1988), architect-scholar widely known for his reconciliation of vernacular Turkish architecture with modern design, documented traditional buildings since he was a student-architect at the Academy of Fine Arts, Istanbul. Years later, Eldem initiated "Milli Mimari Semineri" (National Architecture Seminar) at the academy when he was a professor of architecture. ${ }^{16}$ In the 1930 and 1940 , his students prepared measured drawings of houses and mansions across Anatolia. Nalbantoğlu stresses that Eldem's documentation ${ }^{17}$ of vernacular fabric aligns more with that of a natural scientist than of a historian as he utilized the learned gaze of the modern professional to record and classify the anatomy of a house. In the end, neither the ethnic diversity of users nor their social status, customs, or lifestyles were seen significant to note. Translated into practice, the plan types of these houses were modified to be used for the modern houses of Istanbul's Westernized bourgeoisie. ${ }^{18}$

Reassessment of the built environment was, essentially, an act of appropriation. ${ }^{19}$ Once the multilayered architectural heritage across the country was discursively Turkified, a highly ordered building system based on typology and morphology governed the formal analysis of architecture. ${ }^{20}$ Compartmentalized by building types (of mosques, madrasas, tombs,

values of architecture became central in the design competition for the mausoleum of Atatürk, Anıtkabir, in Ankara. Soon after Atatürk's death, the preparations for his official funeral, along with the discussions and decisions about Anitkabir, got entangled with the representation of the idealist and nationalist sentiments in the new country; see Christopher S. Wilson, "Representing National Identity and Memory in the Mausoleum of Mustafa Kemal Atatürk," Journal of the Society of Architectural Historians 68, no. 2 (2009): 224-253.

14 In this end, reading the built environment through modernism expanded in some European narratives, for example the Swiss and French architect and theorist, Charles-Édouard Jeanneret's, known as Le Corbusier, depiction of Sinan's design, the mosque of Sultan Selim. In Le voyage d'Orient (Paris: Forces Vives, 1966); Le Corbusier noted the pure geometric form of the mosque. Likewise, Ernst Arnold Egli, an Austrian and Swiss architect and theorist, translated the design of Sinan's mosques to a cube-and-dome combination. See, Ernst Egli, Sinan: Der Baumeister Osmanischer Glanzzeit (Zurich, 1954); published in Turkish, Sinan: Osmanlı Altın Çağının Mimarı, trans. ibrahim Ataç (Istanbul: Arkeoloji ve Sanat Yayınları, 2009).

15 Sibel Bozdoğan, "Reading Ottoman Architecture through Modernist Lenses," Muqarnas 24 (2007): 199-201.

16 Eldem was an assistant of Egli at the Academy of Fine Arts. In fact, Egli initiated Eldem's interest in offering the National Architecture Seminar; see, Neslinur Hızlı and Nezih R. Aysel, "Ernst Egli’nin Güzel Sanatlar Akademisi Mimarlık Eğitimi Reformu Çalışmaları,” in Ernst A. Egli, Türkiye’ye Katkılar, ed. Ali Cengizkan, Selda Bancı, and N. Müge Cengizkan (Ankara: TMMOB Mimarlar Odası Yayınları, 2017): 79-80. The expansion of the nationalist position in architectural historiography can be attributed to the views of German and Austrian art historians such as Joseph Strzygowski (1862-1941), Heinrich Glück (1889-1930), and Ernst Diez (1878-1961), who endorsed ethno-racial theories which highlighted the westward dissemination of "Aryan" artistic forms through the nomadic migrations of the Turks; see Gülru Necipoğlu, "Creation of a National Genius," Muqarnas 24 (2007): 141-183. Also, see, Oktay Aslanapa, Türkiye'de Avusturyalı Sanat Tarihçileri ve Sanatkârlar: Özellikle Atatürk Devri’nde (Istanbul: Eren, 1993).

17 Documentation includes the systematic examination and analysis of historic properties to produce a compilation of data about a site, structure, object, or event. The purpose of the documentation activity is to collect, organize, explain, and illustrate information that is relevant to the current understanding of the past and to present an intellectual infrastructure of the entity in question; see Serra Akboy-ilk, "Crafting the Architectural Measured Drawings," The Plan Journal 2, no. 1 (2017): 39-61.

18 Gülsüm Baydar Nalbantoğlu, "Between Civilization and Culture: Appropriation of Traditional Dwelling Forms in Early Republican Turkey," Journal of Architectural Education 47, no. 2 (1993): 68, 71.

19 Ümit Fırat Açıkgöz, "On the Uses and Meanings of Architectural Preservation in Early Republican Istanbul (1923-1950)" in Journal of the Ottoman and Turkish Studies Association 1, no. 1-2 (2014): 170; Pınar Aykaç, "The Commission for the Preservation of Antiquities and Its Role in the Appropriation of lstanbul's Diverse Heritage as National Heritage (19391953)" New Perspectives on Turkey 62 (2020): 76. Both Açıkgöz and Aykaç stress that the appropriation of architectural heritage in the early republic culminated in the fluid strategies for the curatorial management of historic properties. 20 Oya Pancaroğlu, "Formalism and the Academic Foundation of Turkish Art in the Early Twentieth Century," Muqarnas 24 (2007): 67-68. 
baths, fountains, and vernacular architecture), a strict hierarchical framework perpetuated. A mosque with a central dome would be distinctly separated from counterparts with multi-units or a madrasa with an open courtyard from an enclosed one. Subsequently, a morphological breakdown of materials and structural elements (such as support systems, column capitals, arches, fenestration, portals, and mihrabs) became the major unit of analysis. Hence, two-dimensional plans acquired epistemic importance over other drawing conventions of sections, elevations, or perspectives, and these planimetric illustrations showcased the limited set of terms with which the Ottoman built environment was conceptualized.

Early republican scholars harmonized an understanding of formalism in the composition of function and structure. Function was not seen as an autonomous facility that had to be bracketed out along with other contextual aspects but as an internal force through which forms emerged. An exquisite architectural form, therefore, was conceived as the outcome of the rational procedure of a careful consideration of function and structure. ${ }^{21}$ In reality, formalism devoted itself single-mindedly to the aesthetic properties of the work and deliberately focused on the genius of the artist-in our case Sinan-only insofar as it became expressed in the individual work.

Sinan emerged in this nationalist/modernist paradigm as a prodigy who achieved "monumental volumes and harmonious building blocks." ${ }^{22}$ This period was referred to as the "classical period" of architecture, and Sinan's mosques became the zenith in the history of Turkish architecture, resonating with the eternal pursuit of Turkish architects to create a building type with a centralized domed system. Sinan's realization of mosque design was prescribed as a form of functionalism through his dedication to achieve a centralized congregational space supporting the actions and statements that surrounded the physical entity of prayer in the faith of Islam. Republicans' depiction characterized the pure geometric forms, volumetric massing, proportion, structural rationalism, and lack of ornamentation as the gist of Sinan's forms in the service to functionalism.

\title{
Universalism Embodied in the Kara Ahmed Pasha Mosque
}

\begin{abstract}
On the northern side of the seventh hill of Istanbul, on a dominating location overlooking the Bayrampasa stream, there exists the Topkapi Ahmed Pasha Mosque complex, which is composed of a mosque, madrasa, mausoleum, elementary school, and fountain. Since the [buildings of the] complex are scattered in response to topography, the site plan is not symmetrical or methodical. In this work of art, the great architect Sinan created a very handsome example. [The chief architect] erected the pious foundation of Kara Ahmed Pasha in the most picturesque location in the city. This achievement belongs to the unique oeuvre of Sinan. ${ }^{23}$
\end{abstract}

Where does Ülgen's (1913-1963) statement on the Kara Ahmed Pasha Mosque leave us? Can we label the design and planning of the mosque complex rational or unorthodox? To be fair, revealing Ülgen's legendary authority in Turkish architecture is itself naïve just probing a descriptive paragraph, but his torrent of words depicts the perception of the built environment in early republican Turkey. An architect and scholar whose phenomenal work shaped the field of architectural preservation in Turkey, Ülgen addresses the rational planning principles embedded in the design, and his work resonates with strict formalism. ${ }^{24}$ Given this, Ülgen describes the composition and site of the complex in the national matrix of Turkish architecture and considers the Kara Ahmed Pasha Mosque as an exquisite example of Sinan's creativity.

21 Millard Fil Hearn, The Architectural Theory of Viollet-le-Duc: Readings and Commentary (Cambridge, MA: MIT Press, 1995), 12-13. To Hearn, modern architectural theory is extensively based on the rearrangement and magnification of the theories of French architect-scholar Eugène Emmanuel Viollet-le-Duc (1814-1879), who searched for rational precepts embedded in historic architecture.

22 Ekrem Akurgal, "Sanat Tarihi Bakımından Sinan," Ankara Üniversitesi Dil ve Tarih - Coğrafya Fakültesi Dergisi 2, no. 3 (1944): 373-374. Akurgal, sent by the Turkish government to study in Berlin from 1932 to 1941, was the first professor of classical archaeology at the newly founded Ankara University. Akurgal's scholarship heavily resonated with formalist art criticism focusing on stylistic analysis for dating and context.

23 Ali Saim Ülgen, Topkap̧ida Ahmed Paşa Heyeti (Ankara: Vakıflar Umum Müdürlüğü Neșriyat1, 1942), 169.

24 Akboy-ilk, "Ali Saim Ülgen: A Dialectical Frame of the Republican Mind," Tasarım Kuram 15, no. 28 (2019): 96-110; and Akboy-ilk, "Ali Saim Ülgen: Building a Historiography of Turkish Architecture," Turkish Historical Review 10, no. 1 (2019): 71-97. 
In terms of its architectural form, the ashlar masonry of the Kara Ahmed Pasha Mosque has a rectangular plan. The mosque is located in an enclosed garden where a rectangular porticoed courtyard, partially encircled by the rooms of the madrasa, fronts the prayer hall. The porch leading to the prayer hall includes five dome-capped bays, and a minaret with a single şerefe is located in the corner space between the porch and the prayer hall. The latter has a rectangular ground plan with a hexagonal baldachin rising from six red granite columns. The central dome is abutted by four half domes. The lateral spaces beyond the half domes are vertically divided through a mahfil (gallery). These galleries are divided by buttress insets that contain internal staircases. Grouped in pairs, close to the qibla and anti-qibla walls, the granite columns transmit the pressure of the central dome to the buttress insets into the wall. To Ülgen, the granite columns fronting the walls are harmonious with the buttresses, culminating in a "monumental and elegant" form. ${ }^{25}$

At a large extent, formalist surveys focused on the variations of domes and plan types embodied in Sinan's forms. To Doğan Kuban, an architect and historian whose work on Ottoman architecture has resonated with generations of scholars, Sinan's universal contribution to the history of design included the structural rationalism of domed baldachins as the modular and formal element. ${ }^{26}$ Concurrently,

With a conscious effort, Sinan has pushed the potential of the "domed baldachin" (or the structural unit) to its possible units. He attains the perfect symmetry of Şehzade at the very first step. The structural baldachin borne on six columns, taken from Üç Şerefeli Mosque and improved, goes all the way from Sinan Paşa Mosque to Atik Valide. The design of Selimiye is the ultimate stage for the geometry of the primitive transition between the square base and the circular rim of the dome. ${ }^{27}$

Once read as a precursor to other mosques of Sinan, under whom the domed construction reaches the highest degree of development and flexibility, the formalist paradigm would abide no contamination of the pure conceptual response to the form of Kara Ahmed Pasha's mosque. ${ }^{28}$ To Oktay Aslanapa (1914-2013), the renowned art historian and scholar who dedicated his life to the study of the national art and architecture of Turks, the essence of the mosque of Kara Ahmed Pasha included its rational hexagonally domed baldachin. Aslanapa secured a visual comparison of the historic structure with an architectural precedent, the fifteenth-century Üç Şerefeli Mosque in Edirne (fig. 7). Aslanapa assumed Sinan's interest in a hexagonal baldachin system is engrained in the scale and proportion of the structural elements of the Üç Şerefeli Mosque. Resonating with a pure taxonomical gaze, Aslanapa wrote,

[...] in the mosque built for the Vizir Kara Ahmed Pasha at Topkapı in Istanbul [...] the plan of Üç Şerefeli Mosque] is slightly altered by placing the columns supporting the arches which form a hexagon under the dome a little to the front of the walls, removing the two domes on each side and filling the corners with quarter-domes enlarged by exedras, thus leaving only a space the depth of two niches for the side galleries. ${ }^{29}$

Ülgen conditioned the rationale of Sinan through the chief architect's use of scale and proportion: "[...] The great architect Sinan, with his work of the Kara Ahmed Pasha Mosque, bestowed another version of this form to our architectural history [...] supporting the main dome with half domes, Sinan achieved an exceptionally proportioned exterior mass."30 "The calculated relationship between the exterior and interior and the lightness of the space" is a result of the application of a hexagonal baldachin layout with the support of four half domes, Ülgen wrote. ${ }^{31}$ Reducing the side domes to half domes set at an angle of forty-five degrees, Sinan alleviated the rigid compartmentalization of Üç Şerefeli and "energized an exterior volume with exceptional

25 Ülgen, Topkapida Ahmed Paşa Heyeti, 169.

26 Kuban, Sinan's Art and Selimiye, 7.

27 lbid., 6.

28 To the German architectural historian Cornelius Gurlitt, the Kara Ahmed Pasha Mosque was one of the most outstanding buildings in Ottoman architecture. Gurlitt's book Die Baukunst Konstantinopels (1907), then translated to Turkish, was the earliest European monograph to recognize the originality of the Turkish school of architecture; see Cornelius Gurlitt, Istanbul'un Mimari Sanatı, trans. Rezan Kızıltan (Ankara: Enformasyon ve Dokümantasyon Hizmetleri Vakfı, 1999 ), 76. 29 Aslanapa, Turkish Art \& Architecture, 222. Aslanapa, who obtained his doctoral degree from Vienna University, was heavily influenced from formalist criticism of art history and interpreted Turkish art and architecture in a formalist manner coinciding with nationalist ideals.

30 Ülgen, Topkapidda Ahmed Paşa Heyeti, 160 .

31 lbid. 


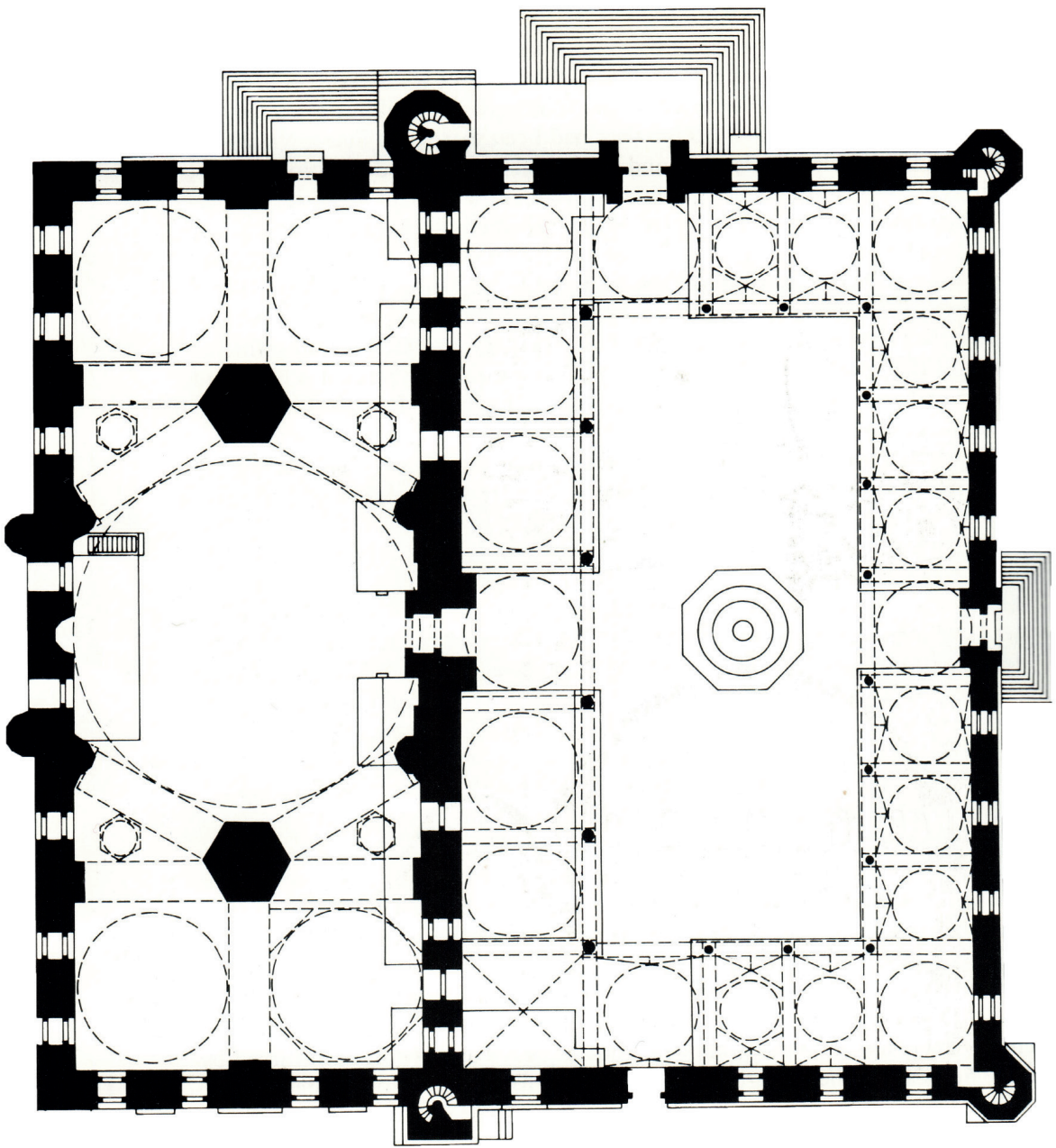

Figure 7: Floor plan of Üç Şerefeli Mosque, Edirne (Goodwin, A History of Ottoman Architecture, 98).

proportion" in the Topkapi Mosque, in return preventing the "dullness" of a single dome merely resting on a hexagonal drum. ${ }^{32}$

Yet, in the mosque of the late pasha, the side galleries adjacent to the dome did not satisfy the formalist analysis of universally valid geometric rules. Labeled as exploratory in the service to achieve a unified interior space to be more fully integrated, authors compared the monument in Topkapı with comparable mosques of hexagonal baldachins. Kuban read Sinan's experimentation of centralized space as follows:

[...] in the Mosque of Ahmet Pasha, the main supports are pillars connected to free-standing columns; this doubling of supports and the creation of a kind of ambulatory around the center was an ancient device. To inscribe a hexagonal baldachin in a rectangular enclosure, half domes were used to cover the four corners. The solution to the problem of the side aisles (covered by small domes in this mosque) is found in the Sokollu Mehmet Pasha Mosque, where the side aisles are eliminated.33

To formalism, art objects possess immutable characteristics that communicate across time and space. ${ }^{34}$ In retrospect, formalist authors assumed a correctness and a universalism engrained

32 lbid.

33 Doğan Kuban, "Architecture of the Ottoman Period," in The Art and Architecture of Turkey, ed. Ekrem Akurgal (New York: Rizzoli International Publications, 1980), 145-146.

34 Karen A. Hamblen, "Beyond Universalism in Art Criticism," in Pluralistic Approaches to Art Criticism, ed. Doug Blandy and Kristin G. Congdon (Bowling Green, OH: Bowling Green State University Popular Press, 1991), 7-14. Although Hamblen's narrative mainly resonates with the formalist reading of abstract painting of the early twentieth century, her assessment is 
Figure 8: Left, the existing floor plan of the Kara Ahmed Pasha Mosque; right, Egli's proposed layout (Egli, Sinan: Osmanlı Altın Çağının Mimarı, 123).
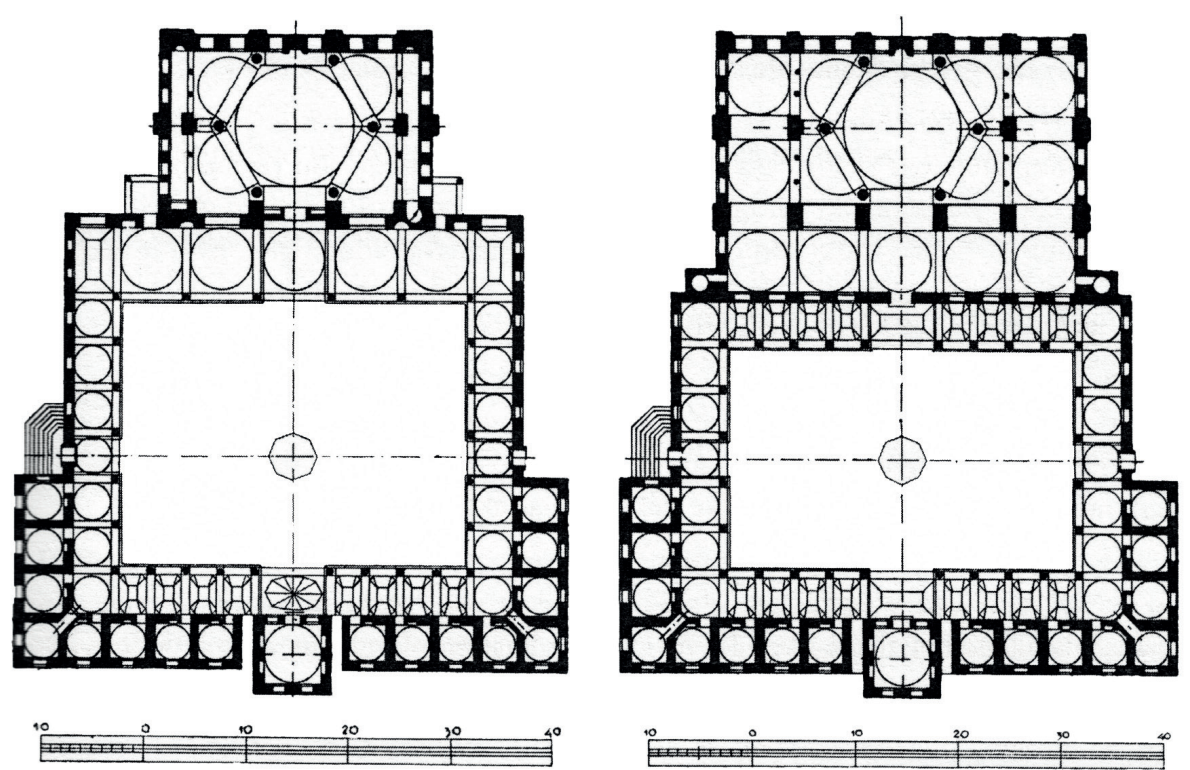

in all Sinan's works. If a historic property failed to meet the rational linkages to parallel the evolvement of unified space, it took on the formalists to validate the artistic expression and assumed universal presence. Ernst Arnold Egli's (1893-1974) analytical probing of the artistic roots of the Topkapı Mosque confirms this missionary zeal of absolutism. ${ }^{35}$ To Egli, an Austrian and Swiss architect and theorist who designed numerous public buildings in Ankara, the posthumous Kara Ahmed Pasha's mosque was not constructed based on Sinan's initial design. Egli reckoned the memorial monument did not meet the grandiosity of a grand vizierial bequest, which had been aptly executed in the mosque and madrasa of the grand admiral Sinan Pasha ${ }^{36}$ in Beşiktaş (ca. 1555-1556). ${ }^{37}$ Egli assumed that the chief architect's reasons for the grand vizierial mosque of Kara Ahmed Pasha essentially lie in the purity of "his initial and original form." ${ }^{8}$ Interestingly, Egli fabricated a floor plan (fig. 8) based on a comparative analysis with Sinan Pasha's memorial bequest. With its hexagonal baldachin flanked by double domes on each side, the late grand admiral's mosque in Beşiktaş, together with the U-shaped madrasa in the same courtyard, is comparable to the endowment of Kara Ahmed Pasha. Egli would easily succumb to claims of universalism and speculate his own proposed floor plan as the rational form that Sinan must have considered for Kara Ahmed Pasha's mosque:

The proposed form of the mosque of the grand vizier [Kara Ahmed Pasha], both in terms of scale and splendidness, now correspond to the grand admiral Sinan Pasha's mosque, which also has a plan with lateral halls confirming to a hexagon. Most likely, the authentic portico [son cemaat yeri] was later added to the interior space. I think, the replacement of the inner portico with a very ornate second narthex upholding the

crucial in understanding the shortcomings when formalism is applied to the history of architecture. Hamblen delivers the analogy of a painting to a window with a view of a garden. To Hamblen, prior to the twentieth century, the viewer would look through the window (painting) to the garden beyond and recognize types of vegetation, cloud formations, and people in the garden. Personal associations, cultural readings, and memories are allowed in the view of the garden. In contrast, in the formalist theory of the twentieth century, the viewer is to eschew all personal and cultural associations and look only at the flat surface of the window pane itself, on which are seen the garden's abstracted colors, textures, and shapes. 35 The pursuit of rationalist design was also evident in Egli's understanding of historic preservation. During his residency in Turkey, Egli swung between two poles of preservation treatments. To bring European norms of orthogonal road patterns to Anatolian cities, Egli promoted the replacement of irregular organic forms with rational modern settlements. Yet, in this route, the extent of demolition of the vernacular fabric remained elusive. During a lecture in 1936, Egli promoted integrating the existing one-way streets to the rational grid system. In a subsequent lecture, however, he supported the replacement of all the authentic fabric; see Esra Akcan, Architecture in Translation: Germany, Turkey, and the Modern House (Durham, NC: Duke University Press, 2012), 168-169.

36 The grand admiral Sinan Pasha was the brother of the grand vizier Rüstem Pasha.

37 Ernst Egli, Sinan: Osmanli Altın Çağının Mimarı, trans. Ibrahim Ataç (Istanbul: Arkeoloji ve Sanat Yayınları, 20o9), 122. Drafts of Egli's book can be accessed from SALT Research, TASUDOCM0295, TASUDOCA0071, and TASUDOCMo295E1. 38 lbid., 125 . 


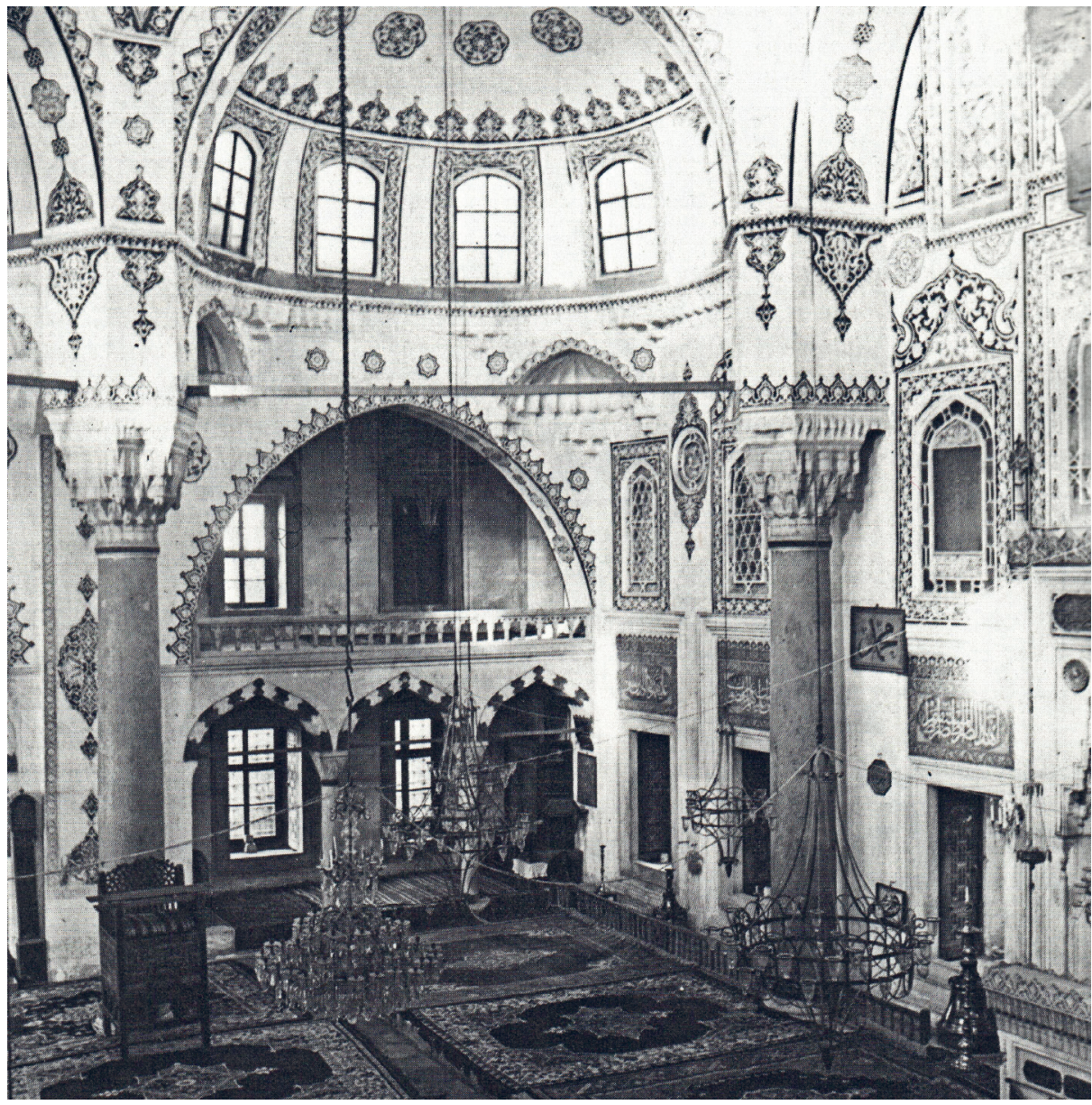

Figure 9: Interior of the Kara Ahmed Pasha Mosque (Goodwin, A History of Ottoman Architecture, 246).

extension of the courtyard would have been a more reasonable solution. This narthex, naturally, corresponds to the colonnade fronting the madrasa. By this way, the side gates of the courtyard of the mosque would have been aligned with the axial line going through the ablution fountain. The minarets, perhaps, would have been located outside of the exterior corners of the lateral naves. By this means, the mosque would have been in proportion with the courtyard, which would have resulted in the purer and improved version of the unique construction idea of the Sinan Pasha Mosque in Beşiktaş. ${ }^{39}$

For many republicans, what distinguished Turkish architecture included the preeminence of tectonic and volumetric concerns over decorative impulses..$^{40}$ Republicans' reasoning was deep-rooted in their firm stance in countering the biases of the orientalist European scholarship, which advocates a stagnant East in contrast to a dynamic and progressive West. This skewed thinking culminated in enduring assumptions about the lack of an internal discourse on rational architecture coming out of the Islamic context. In presenting the architectonic qualities of Sinan's forms equivalent to the status of the "privileged" styles of the Western world and as a rational, structural, and universally applicable system of building, subject to continuous change and innovation, the early republicans manifested the national architecture of Turks. ${ }^{41}$ Ülgen's elaboration of the surface decorations of the interior of Kara Ahmed Pasha accompanied this essentialist outlook (fig. 9-10). Excluding an epigraphic study that would have broadened the range of information on the making of the mosque and on its patron, Ülgen solely drew attention to the formal categories of artwork: richness of materials, inventiveness in surface finish, quality of execution, and composition of color:

39 Ibid. The emphases are mine.

40 Bozdoğan, "Reading Ottoman Architecture," 209.

41 lbid., 203-208. 
Figure 10: Minbar of the Kara Ahmed Pasha Mosque. SALT Research, Ali Saim Ülgen Archive, TASUH4656.

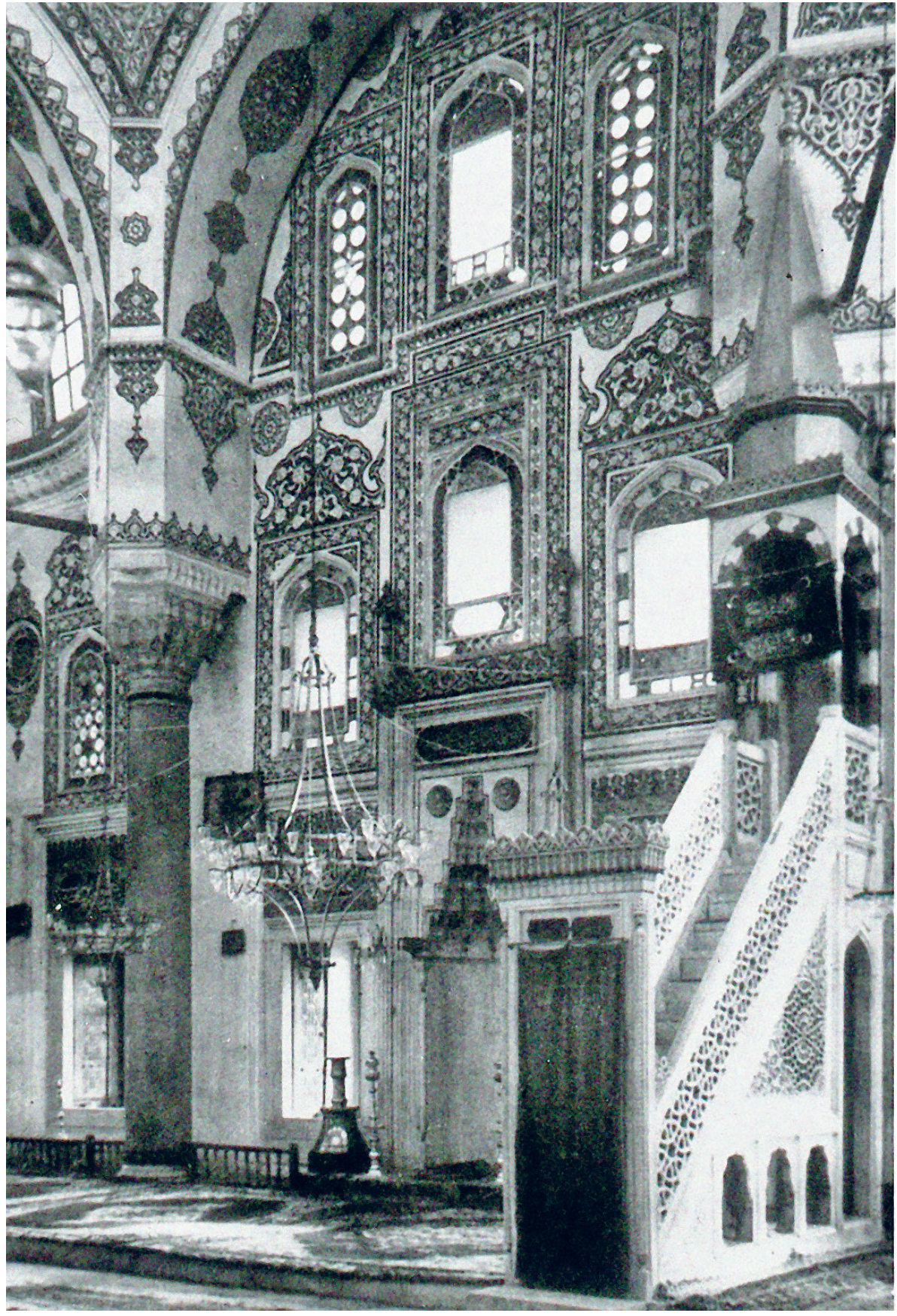

The interior decorations of the mosque, windows, and especially the mihrab and minbar made of marble are very handsome. The tiled lunettes above the windows are rare pieces in terms of color and composition, which interests tile specialists. Although the interior of the mosque receives abundant light, the mystical effect is not weak. The exquisite craftsmanship of marble in this monument ranks among the masterpieces of Turkish art. Particularly, the finely sculpted minbar is stunning. ${ }^{42}$

In effect, Yaltkaya holds a very limited discussion on the epigraphic work. Yaltkaya's translation of some Koranic inscriptions showcases a generic epigraphic program. The central 


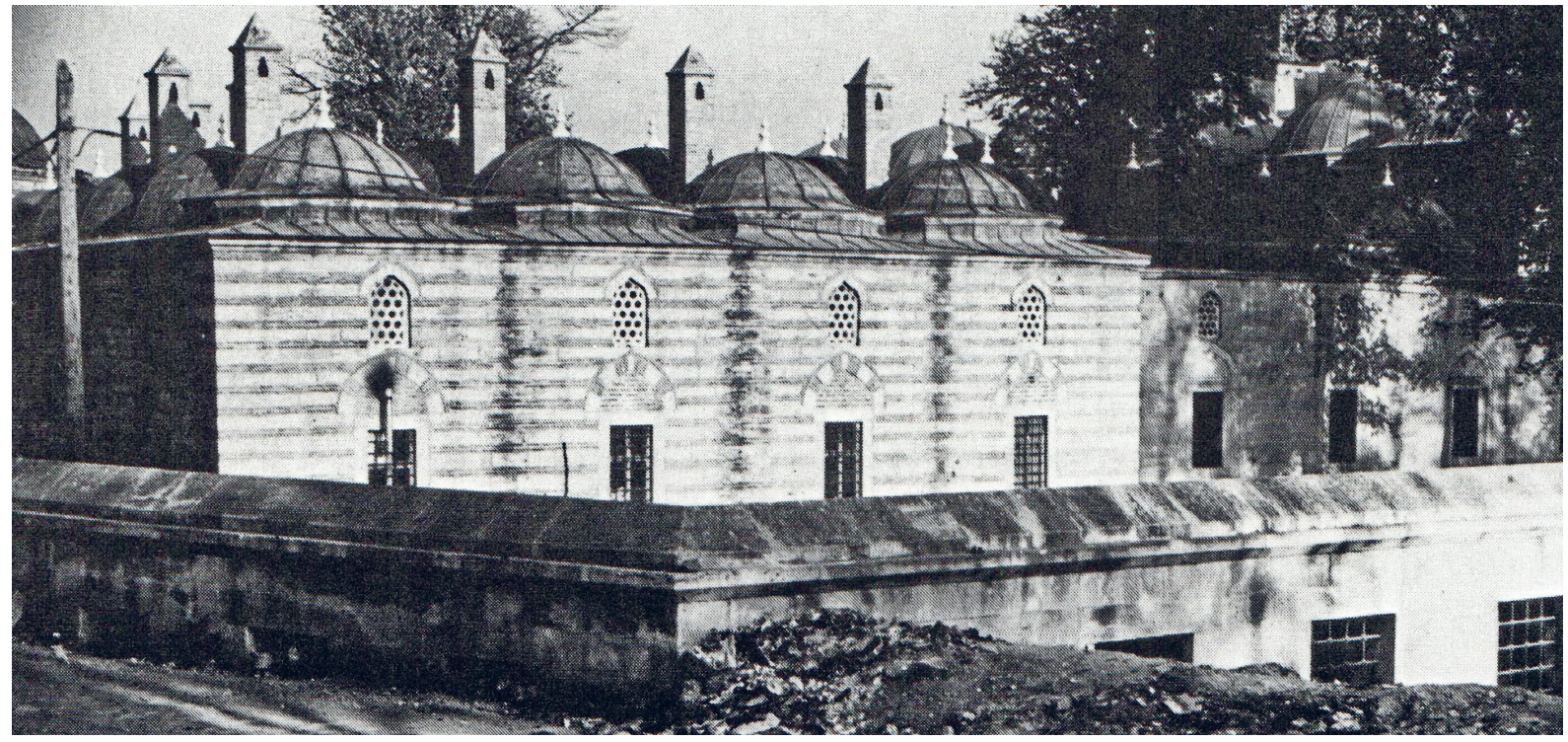

roundel of the dome quotes the Ikhlas sura (112:1-4), affirming the unity of the merciful God while the painted roundels on the six domes arches cite the Fatiha sura (1:1-7), begging the merciful God to guide the congregation toward the straightway in the Day of Judgment. Furthermore, Yaltkaya notes the inscribed tughra of the Abdülhamid II (r. 1876-1909) on the precinct gate, which commemorates the repairs conducted between 1896 and 1897. Yaltkaya records an inscription dedicated to Ahmedzade Topkapıll, who was buried in the premises. ${ }^{43}$
Figure 11: Madrasa of the Kara Ahmed Pasha Mosque Complex, street view (Goodwin, A History of Ottoman Architecture, 247).

\section{Contributing Properties in the Grand Vizierial Complex}

The context-free emphasis of the formalist school of thought symbiotically coalesced with the scientific study of Sinan's architecture. The differential class-based manner of formalism, however, created an academic focus on the mosque as an entity in its own right, while denigrating other building types. To Ülgen, for example, the mosque constituted the most exquisite fragment of the endowment of Kara Ahmed Pasha with its meticulously applied details.

\begin{abstract}
...Whether observed from Yenibahçe or Edirnekap1, the fine selection of the location of the mosque confirms the application of urban planning perspectives. The most exquisite and thoroughly handled fragment of the complex, the mosque, embodies a powerful massive appearance [experienced] from the lower neighborhoods. Even seen from further districts of the city, the mosque is observed like a crown of the Topkapı neighborhood. ${ }^{44}$
\end{abstract}

To this end, the mausoleum and the elementary school are neither "exceptionally configured" buildings nor embody "architectural significance." 45 Sharing the courtyard with the mosque, the madrasa units only serve to bolster the monumental appearance of the mosque, Ülgen heralded. ${ }^{46}$

On the northside of the courtyard, the madrasa (fig. 11) is in the midst of a cluster of sixteen cells, five in a row on each side on the north with three down the east and west sides that form

43 Necipoğlu, The Age of Sinan, 384; Yaltkaya, Kara Ahmed Paşa Vakfiyesi, 96-97.

44 Ülgen, Topkapi'da Ahmed Paşa Heyeti, 169.

45 lbid.

46 Ibid., 17o. In the early republican period, the creation of public spaces and modern facilities became instrumental to reinforce reforms; see Cânâ Bilsel, "Remodelling the Imperial Capital in the Early Republican Era: The Representation of History in Henri Prost's Planning of Istanbul," in Architecture and Power in the Ottoman and Turkish States, ed. Jonathan Osmond and Ausma Cimdina (Pisa: Edizioni Plus, Pisa University Press, 2007), 95-115. One major example to early republican urban planning projects include the construction of Sümerbank facilities across the country. The architecture of factories, residences, and social amenities at Sümerbank facilities reflected a national identity within Turkish modernity: modular, functional, adaptable, standardized plan layouts and facade treatments; durable, local, and accessible construction materials; and unisex public spaces promoting a secular and rational lifestyle; see Dilek Himam and Burkay Pasin, "Designing a National Uniform(ity): The Culture of Sümerbank within the Context of the Turkish Nation-State Project," Journal of Design History 24, no. 2 (2011): 157-170. 
Figure 12: Mausoleum of Kara Ahmed Pasha, street view. SALT Research, Ali Saim Ülgen Archive, TASUH8505.

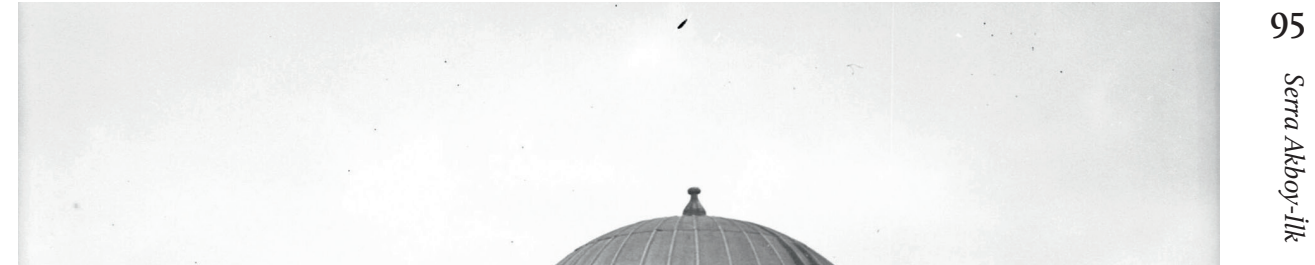

永

wings. Domical arcades extend between the mosque and the side wings of the madrasa. The square-planned cells are each tapped with a dome and surrounding low vestibule porticos. At the center of the cells, the domed classroom is aligned with the ablution fountain on the mihrab axis. Between the cells and the classroom are two slypes that lead to the lavatories and a small garden. To Ülgen, the structural rationalism of the madrasa epitomizes a clearly legible architectural concept of cubes and domes in various scales to create a hierarchical progression with the mosque as the focal point. ${ }^{47}$

Accordingly, the ashlar masonry mausoleum of Kara Ahmed Pasha (fig. 12) distinguishes with its pure form. The tomb, clustered with the elementary school outside the enclosure of the mosque and madrasa, is a double-shell, domed hexagon with one aperture per side. The "inelegantly tall" masonry mausoleum has a hexagonal exterior and a dodecagonal interior, with an atypically 


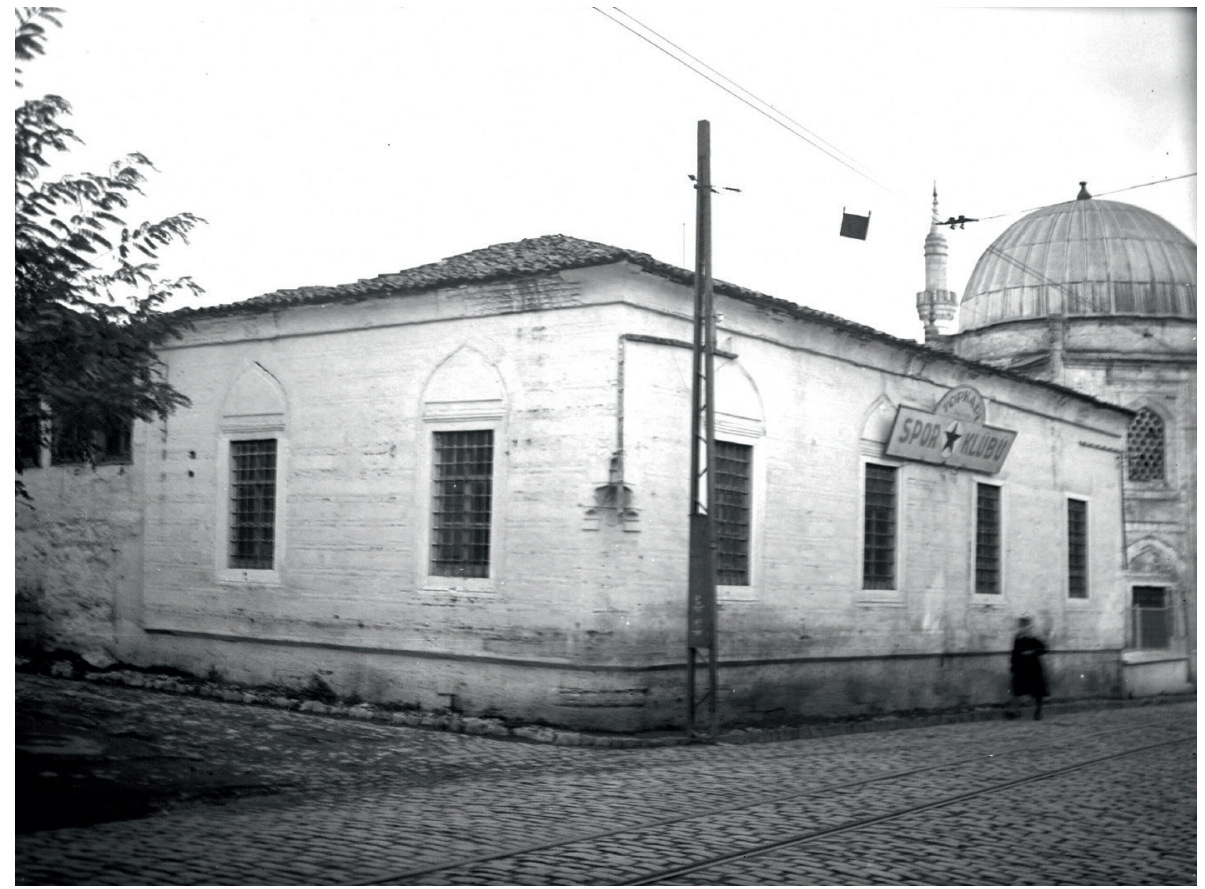

Figure 13: Elementary school of the Kara Ahmed Pasha Mosque complex, street view. SALT Research, Ali Saim Ülgen Archive, TASUH8602.

bulbous double-shell dome raised on an eighteen-sided drum. Ülgen probed the volumetric discrepancy between the exterior and the interior appearances and concluded that Sinan utilized a double-shell dome with the purpose to maintain a proportionate interior space. ${ }^{48}$

Interestingly, the renowned architectural historian Aptullah Kuran (1927-2002) interpreted the configuration of the mausoleum through notions of interiority and exteriority. For $\mathrm{Ku}-$ ran, an architect trained with the modernist conceptual apparatus, the evolution of forms was evident in the continuity of Anatolian architecture. ${ }^{49}$ In this context, Kuran read the mausoleum of Kara Ahmed Pasha as a pioneering design of Sinan in which the chief architect experimented with "the prismatic organization" of the building block. To Kuran, the interior space, a prism made of twelve wall surfaces tapped with a blind dome, exhibited Sinan's experimentation to establish the relationship between inside and outside. Sinan achieved a round interior space with the doubled size of the walls and the blind dome from the inside, while the limited number of walls with a higher dome reinforces the vertical form of the structure from the outside. The evolution of the prismatic organization is observed in the mausoleums of Haseki Hürrem Sultan, Rüstem Pasha, Sokollu, and Siyavuş Pasha Evladi. Kuran noted that Sinan's conspicuous design is intensified in Siyavuş Pasha Evladı (an octagonal-planned prism with sixteen sides on the outside), where the transparency between the inside and outside appearances is minimized through the elimination of the interior elements in the exterior form..$^{50}$

In the evolutionary path of architectural form, the design of the much-altered elementary school (fig. 13) in the Kara Ahmed Pasha complex did not spark academic interest. Ülgen's taxonomic gaze epitomized a formal description of the two-room school building enclosed by its own precinct wall:

48 lbid.

49 Çiğdem Kafescioğlu and Lucienne Thys-Şenocak, "Introduction: Modernism's Vision, Architecture’s Past: Aptullah Kuran and the Historiography of Architecture in Turkey," in Aptullah Kuran: Selçuklular'dan Cumhuriyet's Türkiye'de Mimarlk/Architecture in Turkey from the Seljuks to the Republic, ed. Çiğdem Kafescioğlu and Lucienne Thys-Şenocak, (Istanbul: Türkiye İş Bankası Kültür Yayınları, 2018), xl.

50 Aptullah Kuran, “Mimar Sinan’n Türbeleri," in Mimarbaşı Koca Sinan: Yaşadığı Çağ ve Eserleri, ed. Sinan Bayram (Istanbul: Vakıflar Genel Müdürlüğ̈̈, 1988), 228-229. 
Figure 14: Ablution fountain of the Kara Ahmed Pasha Mosque complex, courtyard view. SALT Research, AHISTSULTo17.

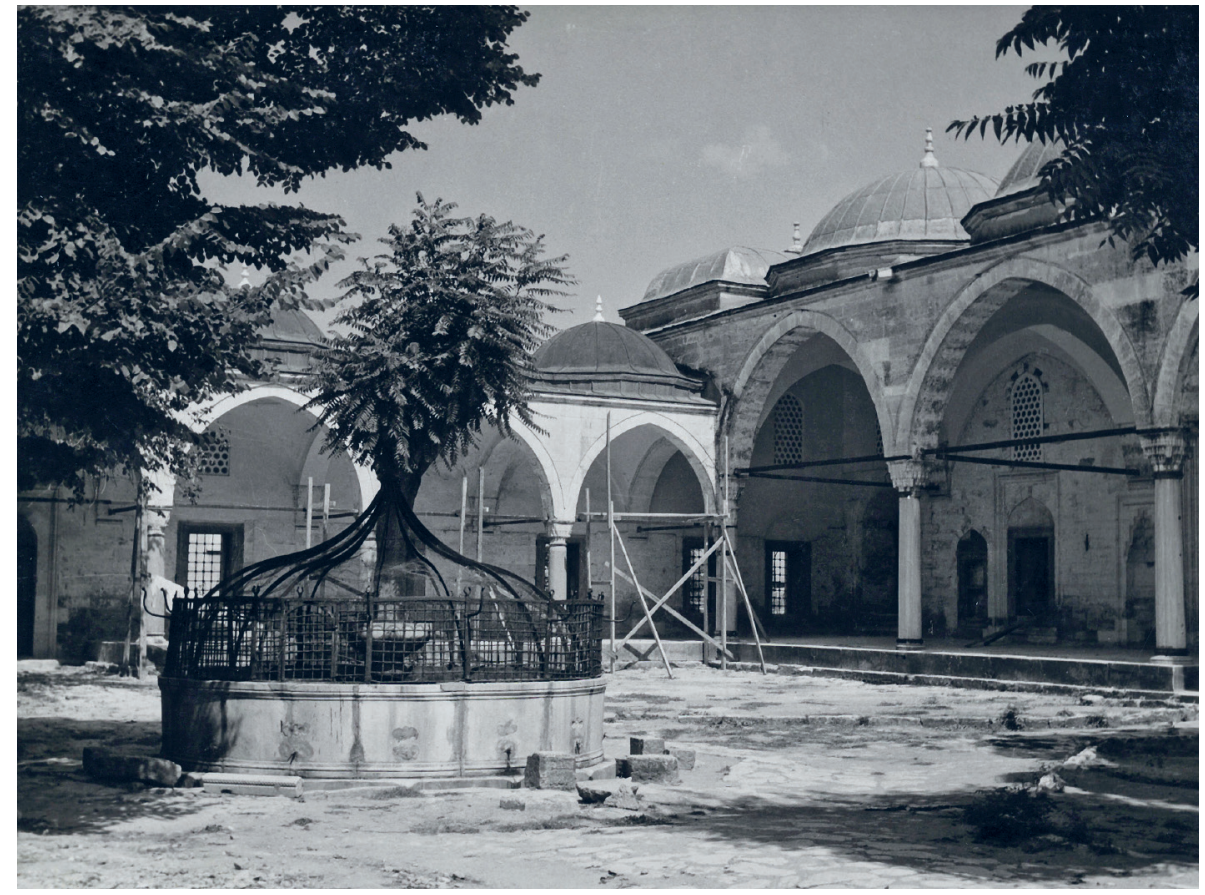

[...] erected at one corner of the complex near Topkapı, is a simple one-story high little building. The school, similar to its counterparts of that era, has a hall and a closed patio overlooking the courtyard with a portico. The building, raised with two steps from the garden, is composed of alternating courses of ashlar stone and brick. The exterior corners of the building are fragmented at a forty-five-degree angle and [the sections] above are decorated with stalactites. The school has four windows facing the street and there are another four on the other sides, two on each. The entrance to the classroom is from the courtyard $[\ldots]^{51}$

Likewise, the ashlar masonry ablution fountain (fig. 14), located between the mosque and the madrasa, did not carry weight in the architectural texts. Ülgen solely noted "the pure, handsome, and proportionate" elements of the fountain covered with a wrought-iron grille canopy..$^{2}$

\section{An Abbreviated Architectural Program}

The fixation on Sinan's purist mindfulness and his universal values, significantly, muted an understanding of the design-build program of the monument. The reflection on the troubled past of Kara Ahmed Pasha largely escaped the formalist construct of architectural form. Except in Mimar Sinan'in Eserleri, an early monograph on Sinan's works, İbrahim Hakkı Konyalı (1896-1984), the renowned historian, traced the contents of the vakfiye (endowment deed) ${ }^{53}$ with the epigraphy work in the mosque complex. Konyali probed

51 Ülgen, Topkapi'da Ahmed Paşa Heyeti, 170-171.

52 lbid., 170.

53 The foundation of the charity of Kara Ahmed Pasha is the vaklf (pious foundation) system. Members of the royal family and ranking officers were active in establishing vaklfs, which provided services for the welfare of the community. In 1926, the Turkish Civil Code [Medeni Kanun] reformulated the concept of the vakuf by secularizing it. It removed the perpetual immunities of the vakıfs and reduced the creation of new ones to almost nil. In 1928, the new Endowments Law, moreover, centralized the administrative and fiscal operations of vakıfs under the newly formed General Directorate of Pious Foundations. The Endowments Law dictated the transfer of all vakıf property and liquid assets to the Treasury if the original mission of the vakıf was no longer valid or there were no surviving regent-heirs. These provisions laid the legal groundwork for a massive transfer of property and liquid assets from vaklfs for use in the materialization of republican projects (e.g., building the new capital, Ankara); see Zeynep Kezer, Building Modern Turkey: State, Space, and Ideology in the Early Republic (Pittsburgh: University of Pittsburgh Press, 2015), 91. 
that the deed, registered on July 21, 1555, prior to the execution of the pasha, does not postulate the exact location of his projected mosque complex. However, the document specifies the contributing buildings: an artistic Friday mosque, a madrasa with sixteen dormitories and a classroom, a dervish convent whose sheikh would deliver sermons at the mosque, an imaret (hospice), and an elementary school. ${ }^{54}$ Neither the hospice nor the dervish convent noted in the vakfiye was constructed. With the same token, the Friday mosque and the madrasa were moved next to the cemetery in Topkap 1 where the pasha had already been buried.

To the vakfiye, a thorough plan of the charities was not even prepared. The mausoleum was not included in the vakfiye, yet, today, we see [the resting place of the pasha] among the properties. Given this, we deduct that during the health of Kara Ahmed Pasha, the construction of the complex did not start. Essentially, the pasha conditioned putting out the endowed properties and the capital to use the accumulated interest in the construction. Since the realization of these [financial] conditions during a limited time of 3-4 months is impossible, the launch of the construction right after the execution of the pasha is an indisputable fact. ${ }^{55}$

Documented in the vakfiye, Kara Ahmed Pasha endowed three million aspers, whose interest would finance the construction of his mosque complex along with numerous real estate properties, including his palatial residence near Yenibahçe, in the Topkapı quarter..$^{56}$ His mosque complex must have been redesigned on the grounds of this garden estate in Topkapi. Plausibly, the initial site was in Karagümrük near Edirnekapı, where the pasha's wife, Fatma Sultan, ${ }^{57}$ had already endowed an elementary school..$^{8}$ Due to the unanticipated outcome of the pasha's execution, however, the project site moved from Edirnekapi to Topkapi. Ten years after the pasha's death, the foundation of his Friday mosque in Topkapı was laid in 1565. Although the mosque and its water channel were completed around 1568-1569, the compound as a whole was inaugurated in $1571-1572.59$

Reading the construction of the monument within the social dynamics of the era, Necipoğlu explains that the construction in Topkapı overlapped with the supportive grand vizierate of Sokollu (fl. 1565-1579), who had fought side-by-side with Kara Ahmed Pasha and was promoted to the vizierate during the late pasha's tenure. Prior to this, the project was suspended during the second grand vizierate of the vindictive Rüstem Pasha (fl. 1555-1561), who is known to have persecuted Kara Ahmed Pasha. Not surprisingly, the construction of a grandiose memorial of an executed grand vizier was reckoned indecorous during Süleyman's reign. Plausibly, the project regained some momentum after Rüstem's demise in 1561, which was entangled with a legal dispute amid his wife Mihrümah. In 1563, the construction of the Friday mosque in Edirnekapı was prohibited during the equally vengeful grand vizierate of Semiz Ali Pasha (fl. 1561-1565), the former governor-general of Egypt against whom Kara Ahmed Pasha had conspired. The foundations for the late grand vizier's memorial mosque were abandoned until Selim Il's reign (r. 1566-1574), when Kara Ahmed Pasha was fully exonerated, and the sultan granted permission to resume construction. ${ }^{60}$

Certain details in the mosque offer an insight on the altered line of work during the construction. The composition of the cuerda seca window lunettes (fig. 15), for example, is the last work of Sinan in which these tiles appear. Cuerda seca, a method to apply colored glazes to ceramic surfaces, fell out of fashion in the 1550 os when imperial buildings were decorated with

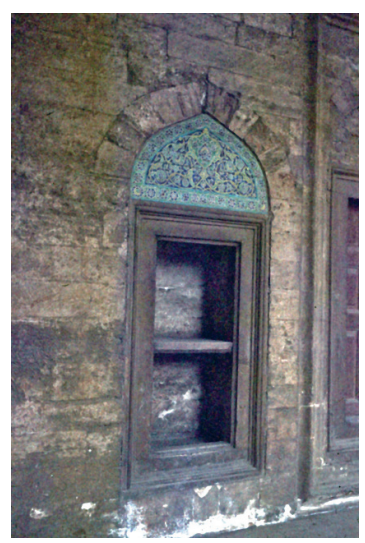

Figure 15: Cuerda seca window lunettes of the Kara Ahmed Pasha Mosque, courtyard view, 1986.

SALT Research, Kemali Söylemezoğlu Archive, TSOH100002.

54 Ibrahim Hakkı Konyalı, Mimar Koca Sinan’n Eserleri (Istanbul: Ülkü Basımevi, 1950), 11; Yaltkaya, Kara Ahmed Paşa Vakfiye, 92-93; Hüseyin Ayvansarâyî, The Garden of the Mosques: Hafız Hüseyin al-Ayvansarâyî̀' Guide to the Muslim Monuments of Ottoman Istanbul, trans. and annot. Howard Crane (Leiden: Brill, 2000), 159, 175, 222. This work is an annotated translation of Ayvansarayîs text, which addresses the Islamic monuments of the Ottoman capital. The original text was completed in 1780 and revised and enlarged between $1832-33$ and 1838 by Ali Sati. It contains separate descriptions of Istanbul's more than eight hundred mosques, along with accounts of madrasas, tombs, tekkes, and other monuments. 55 Konyalı, Mimar Koca Sinan'in Eserleri, 11.

56 Yaltkaya, Kara Ahmed Paşa Vakfiyesi, 88-89.

57 Fatma Sultan was a daughter of the Sultan Selim I (1470-1520).

58 Konyal, Mimar Koca Sinan'in Eserleri, 26.

59 Affan Egemen, İstanbul Çeşme ve Sebilleri (Istanbul: Arıtan Yayınevi, 1993), 107, n. 129.

6o Necipoğlu, The Age of Sinan, 380 . 
Figure 16: Iron-grilled windows of the Kara Ahmed

Pasha Mosque, courtyard view, 1986. SALT Research, Kemali Söylemezoğlu Archive, TSOH100003.

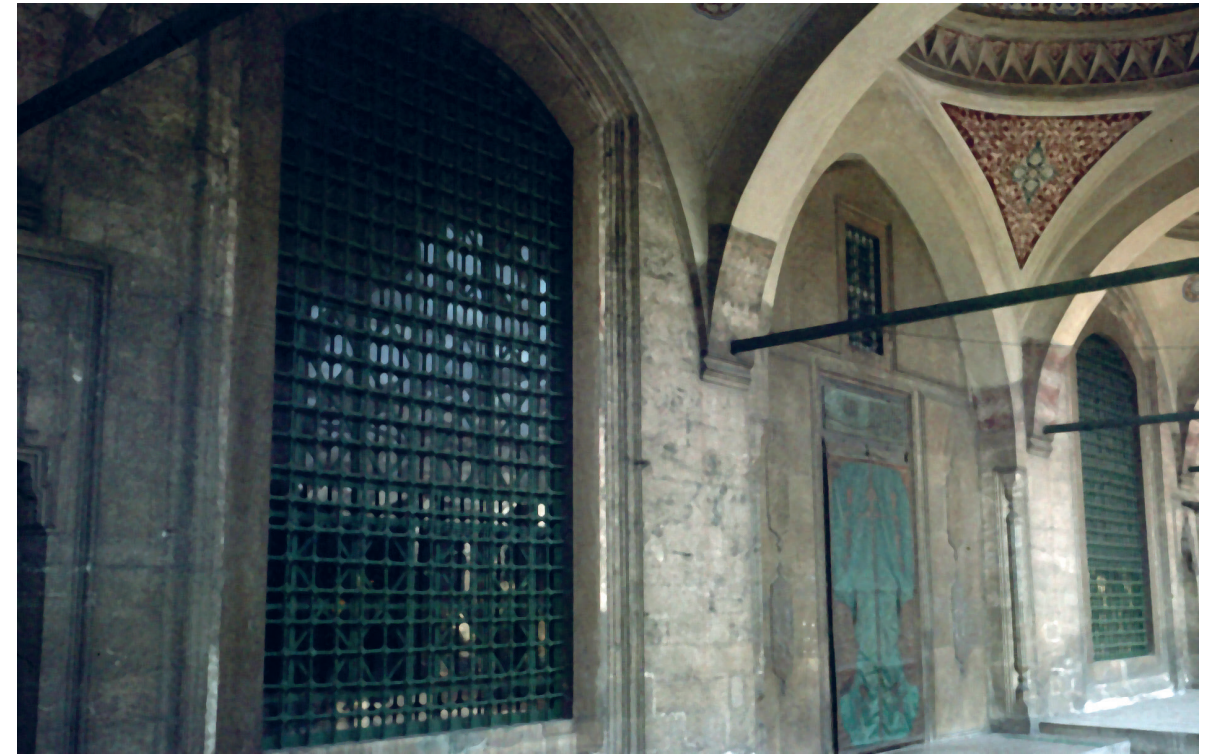

under-glazed tiles from İznik. ${ }^{61}$ The six rectangular cuerda seca window lunettes adorning the qibla wall and the lunettes of two niches with bookshelves on the porticoed north facade are dateable around 1555 in technique, design, and color scheme (yellow, green, blue, turquoise, and white). The preparation of custom-made tiles for the Topkapı Mosque well in advance of its construction confirms the pasha's early provisions, a decade earlier than the actual construction. ${ }^{62}$

Another structural change includes the two enormous iron-grilled windows located by the north gate of the mosque (fig. 16). The scale of windows is comparable to the pair on the double porticoed facade of Rüstem Pasha's Tahtakale Mosque (ca. 1561-1563), where the huge windows maximize the amount of light entering from its north facade. Reasonably, the Topkapı Mosque may have been initially planned with a double portico, in which the two oversized windows, then, would have illuminated the prayer hall into a vigorous space. This modification also explains the five domes of the portico, which are disproportionately large. ${ }^{63}$

To counterbalance the structural weakness of the north facade, pierced with two oversized windows, the other walls in the mosque were reinforced by heavy buttresses, which limit the volume of light filtering into the dimly lit prayer hall (fig. 9). Furthermore, the pasha's other early provision - the six colossal red granite columns-constrained the height of the central dome, which resulted in a relatively cramped prayer hall with unintegrated side aisles. ${ }^{64}$ The concealment of one of the red granite columns behind the finely sculpted minbar, moreover, relegated the harmonious ambiance of the space. ${ }^{65}$ Furthermore, the lateral facades have two tiers of rectangular windows featuring blind lunettes, while the central part of the qibla wall features three-tiered windows. To Necipoğlu, these programmatic changes could not help but turn the grand vizierial monument into a relatively outdated structure, although it was erected during Sinan's tenure as chief architect. ${ }^{66}$ The simple facades of the Topkapı Mosque

61 For example, Rüstem Pasha's grand vizierial mosque (ca. 1563) in Tahtakale, Istanbul is an exquisite example of application of İnik tiles. Arranged in an extensive collection of floral and geometric designs, the tiles cover the façade of the porch, along with the mihrab, minbar, and walls.

62 Necipoğlu, The Age of Sinan, 382.

63 lbid.

64 In Sokollu Mehmed Pasha Mosque, for example, the elimination of side wings from the hexagonal baldachin delivered a more integrated space.

65 Other examples of locating minbar in front of the columns include Atik Valide Mosque and Sokollu Mehmed Pasha Mosque.

66 To Necipoğlu, Sinan must have delegated the execution of the Kara Ahmed Pasha Mosque to one of his assistants. A likely candidate is Davud, who may have supervised the construction of another mosque with a hexagonal baldachin just around the time the complex in Topkapı was completed, that of Nurbanu Sultan in Üsküdar, whose foundation was laid in 1571; see ibid., 382 . 


\section{Concluding Remarks}

Early republican formalists advocated that an architectural work possesses everlasting characteristics and meanings independent from the contingencies of place and time, dismissing the worldly, circumstantial, or socially contaminated contents of history. This strict formalism has resulted in assumptions of universalism that have served to legitimize Sinan's legacy in the history of the nation and to denigrate other architects, artists, or patrons in the process. Emphasis on the uniqueness of Sinan's creativity has also resulted in an isolated, bracketed response to the built environment, which has resonated with an aesthetic goal and talked about the formal qualities of art as a standard of national achievement.

In defense of the universal values embedded in Sinan's creativity, early republican scholars melted the form of the grand vizierial mosque of Kara Ahmed Pasha within the autonomous evolution of hexagonal baldachins. In a chronological outline where Sinan's works became mileposts to display the chief architect's evolving personal creativity, the architectural reading of the Topkapı Mosque was equated to the quest of pure lines, centralized space, and unified domed baldachins. The preoccupation with the abstract clarity, however, hampered an understanding of the troubled past of the pasha and the politics of monumental mosque construction in the development of design, and these historical facts did not find a niche in the essentialist reading of its architectural form.

Not surprisingly, in the texts written in the early republic, the mosque of Kara Ahmed Pasha gained significance due to its visual dominance in the grand vizierial compound. Excluding the building blocks, which have contributed to the organic growth of the built environment, the formalist paradigm sealed the mosque off from the heritage setting. Directing the focus of the research and scholarship solely on the mosque provided limited access to a preselected view of reality. Within self-contained assumptions of national architecture, this skewed position limited the prolific ways of appreciating and understanding the historic complex holistically.

In the matrix of national architecture, Turkish exceptionalism served as a foil for the description of the Kara Ahmed Pasha Mosque complex. The progressive evolution toward purer forms treated the structural and stylistic constituents as a mere pretext for the formalist exercise and displayed pre-established visual constructs (of formal purity, tectonic character, structural rationalism, and lack of ornamentation). The reserved purity imprinted on the buildings in Topkapi contributed to an understanding of the autonomous development of elements and form, which republican theorists equated to the exclusiveness of national unity among Turks. 
Primary Sources

SALT Research

Ali Saim Ülgen Archive

Kemali Söylemezoğlu Archive

Photographs of the Kara Ahmed Pasha Mosque

Published Primary Sources

Ayvansarâyî, Hafız Hüseyin. The Garden of the Mosques: Hafız Hüseyin al-Ayvansarâyî’s Guide to the Muslim Monuments of Ottoman Istanbul. Translated and annotated by Howard Crane. Leiden: Brill, 2000.

\section{Secondary Sources}

Açıkgöz, Ümit Fırat. "On the Uses and Meanings of Architectural Preservation in Early Republican Istanbul (1923-1950)." Journal of the Ottoman and Turkish Studies Association 1, no. 1/2 (2014): 167-185. Akboy-ilk, Serra. "Crafting the Architectural Measured Drawings." The Plan Journal 2, no. 1 (2017):39-61. . "Ali Saim Ülgen: A Dialectical Frame of the Republican Mind." Tasartm Kuram 15, no. 28 (2019): 96-110.

—. "Ali Saim Ülgen: Building a Historiography of Turkish Architecture.” Turkish Historical Review 10, no. 1 (2019): 71-97.

Akcan, Esra. “Asilik sonrası Mimarlık.” In Osmanlı Başkentinden Küreselleşen İstanbul'a: Mimarlı ve Kent, 1910-2010, 133-145. Istanbul: Osmanlı Bankası Arşiv ve Araştırma Merkezi, 2011.

- Architecture in Translation: Germany, Turkey, and the Modern House. Durham: Duke University Press, 2012.

Akurgal, Ekrem. "Sanat Tarihi Bakımından Sinan." Ankara Üniversitesi Dil ve Tarih - Coğrafya Fakültesi Dergisi 2, no. 3 (1944): 373-384.

Aslanapa, Oktay. Turkish Art \& Architecture. New York: Praeger Publishers, 1971.

—. Türkiye'de Avusturyalı Sanat Tarihçileri ve Sanatkârlar: Özellikle Atatürk Devri’nde. Istanbul: Eren, 1993.

Aykaç, Pınar. "The Commission for the Preservation of Antiquities and lts Role in the Appropriation of Ilstanbul's Diverse Heritage as National Heritage (1939-1953)." New Perspectives on Turkey 62 (2020): 75-99.

Banham, Reyner. The New Brutalism. Stuttgart: Karl Kramer Verlag, 1966.

Baydar Nalbantoğlu, Gülsüm. "Between Civilization and Culture: Appropriation of Traditional Dwelling Forms in Early Republican Turkey." Journal of Architectural Education 47, no. 2 (1993): 66-74.

Bilsel, Cânâ. "Remodelling the Imperial Capital in the Early Republican Era: The Representation of History in Henri Prost's Planning of Istanbul." In Architecture and Power in the Ottoman and Turkish States, edited by Jonathan Osmond and Ausma Cimdina, 95-115. Pisa: Edizioni Plus, Pisa University Press, 2007.

Bozdoğan, Sibel. Modernism and Nation Building: Turkish Architectural Culture in the Early Republic. Seattle: University of Washington Press, 2001.

- "Reading Ottoman Architecture Through Modernist Lenses: Nationalist Historiography and the 'New Architecture' in the Early Republic." in "History and Ideology: Architectural Heritage of the 'Lands of Rum,"' edited by Sibel Bozdoğan and Gülru Necipoğlu, special issue, Muqarnas 24 (2007): 199-221.

Bozdoğan, Sibel, and Esra Akcan. Turkey: Modern Architectures in History. London: Reaktion Books, 2012.

Bozdoğan, Sibel, and Gülru Necipoğlu. "Preface: Entangled Discourses." in "History and Ideology: Architectural Heritage of the 'Lands of Rum,"' edited by Sibel Bozdoğan and Gülru Necipoğlu, special issue, Muqarnas 24 (2007): 1-6.

Brockett, Gavin D. How Happy to Call Oneself a Turk: Provincial Newspapers and the Negotiation of a Muslim National Identity. Austin: University of Texas Press, 2011.

Copeaux, Etienne. Tarih Ders Kitaplarinda (1931-1993), Türk Tarih Tezinden Türk Islâm Sentezine. Translated by Ali Berktay. Istanbul: Iletişim Yayınları, 2006.

Egemen, Affan. İstanbul Çeşme ve Sebilleri. Istanbul: Arıtan Yayınevi, 1993.

Egli, Ernst. Sinan: Der Baumeister Osmanischer Glanzzeit. Zurich: Erlenbach, 1954.

—. Sinan: Osmanli Altın Çağının Mimarı. Translated by Ibrahim Ataç. Istanbul: Arkeoloji ve Sanat Yayınları, 2009.

Goodwin, Godfrey. A History of Ottoman Architecture. London: Thames \& Hudson, 1971.

Gurlitt, Cornelius. İstanbul'un Mimari Sanatı. Translated by Rezan Kizıltan. Ankara: Enformasyon ve Dokümantasyon Hizmetleri Vakf1, 1999.

Hamblen, Karen A. "Beyond Universalism in Art Criticism." In Pluralistic Approaches to Art Criticism, edited by Doug Blandy and Kristin G. Congdon, 7-14. Bowling Green, OH: Bowling Green State 
Hearn, Millard Fil. The Architectural Theory of Viollet-le-Duc: Readings and Commentary. Cambridge, MA: MIT Press, 1995.

Hızlı, Neslinur, and Nezih R. Aysel. "Ernst Egli’nin Güzel Sanatlar Akademisi Mimarlık Egitimi Reformu Calısmaları” In Ernst A. Egli, Türkiye’ye Katkılar, edited by Ali Cengizkan, Selda Bancı and N. Müge Cengizkan, 75-84. Ankara: TMMOB Mimarlar Odası Yayınları, 2017.

Himam, Dilek, and Burkay Pasin. "Designing a National Uniform(ity): The Culture of Sümerbank within the Context of the Turkish Nation-State Project." Journal of Design History 24, no. 2 (2011): 157-170.

Isom-Verhaaren, Christine. "A Princess Constructs Ottoman Dynastic Identity." In Living in the Ottoman Realm, edited by Christine Isom-Verhaaren and Kent F. Schull, 150-165. Bloomington and Indianapolis: Indiana University, 2016.

Jeanneret, Charles-Édouard (Le Corbusier). Le voyage d'Orient. Paris: Forces Vives, 1966.

—. Journey to the East. Edited by Ivan Zaknic. Cambridge, MA: MIT Press, 1987.

Kafescioğlu, Çiğdem, and Lucienne Thys-Şenocak. "Introduction: Modernism's Vision, Architecture's Past: Aptullah Kuran and the Historiography of Architecture in Turkey." In Aptullah Kuran: Selçuklular'dan Cumhuriyet's Türkiye'de Mimarlk/Architecture in Turkey from the Seljuks to the Republic, edited by Çiğdem Kafescioğlu and Lucienne Thys-Şenocak, XXXV-XLVII. Istanbul: Türkiye İş Bankası Kültür Yayınları, 2018.

Kezer, Zeynep. Building Modern Turkey: State, Space, and Ideology in the Early Republic. Pittsburgh: University of Pittsburgh Press, 2015.

Konyalı, İbrahim Hakkı. Mimar Koca Sinan'in Eserleri. Istanbul: Ülkü Basımevi, 1950.

Kuban, Doğan. "Architecture of the Ottoman Period." In The Art and Architecture of Turkey, edited by Ekrem Akurgal, 137-169. New York: Rizzoli International Publications, 1980.

- Sinan's Art and Selimiye. Istanbul: The Economic and Social History Foundation, 1997.

Kuran, Aptullah, "Mimar Sinan'ın Türbeleri.” Mimarbaşı Koca Sinan: Yaşadığı Çağ ve Eserleri 1, edited by Sinan Bayram, 223-238. Istanbul: Vakıflar Genel Müdürlüğü, 1988.

Necipoğlu, Gülru. "Creation of a National Genius," in "History and Ideology: Architectural Heritage of the 'Lands of Rum,"' edited by Sibel Bozdoğan and Gülru Necipoğlu, special issue, Muqarnas 24 (2007): 141-183.

- The Age of Sinan: Architectural Culture in the Ottoman Empire. London: Reaktion Books, 2011.

Öndin, Nilüfer. Cumhuriyet’in Kültür Politikast ve Sanat 1923-1950. Istanbul: İnsancıl Yayınları, 2003.

Pancaroğlu, Oya. "Formalism and the Academic Foundation of Turkish Art in the Early Twentieth Century." in "History and Ideology: Architectural Heritage of the 'Lands of Rum," edited by Sibel Bozdoğan and Gülru Necipoğlu, special issue, Muqarnas 24 (2007): 67-78.

Ünsal, Behçet Sabri. Turkish Islamic Architecture in Seljuk and Ottoman Times, 1071-1923. London: Alec Tiranti, 1970.

Wilson, Christopher S. "Representing National Identity and Memory in the Mausoleum of Mustafa Kemal Atatürk." Journal of the Society of Architectural Historians 68, no. 2 (2009): 224-253.

Yaltkaya, Şerefüddin, and Ali Saim Ülgen. Kara Ahmed Paşa Vakfiyesi / Topkapi’da Ahmed Paşa Heyeti. Ankara: Vakıflar Umum Müdürlüğü Neșriyatı, 1942.

Yetkin Suut, Kemal. Türk Mimarisi. Ankara: Bilgi Yayınevi, 1970. 